\title{
Genomic analysis of the nomenclatural type strain of the nematode-associated entomopathogenic bacterium Providencia vermicola
}

\author{
Giuseppe Andolfo $^{1 *}$, Christina Schuster ${ }^{2}$, Haifa Ben Gharsa², Michelina Ruocco ${ }^{3}$ and Andreas Leclerque $2,3^{*}$
}

\begin{abstract}
Background: Enterobacteria of the genus Providencia are mainly known as opportunistic human pathogens but have been isolated from highly diverse natural environments. The species Providencia vermicola comprises insect pathogenic bacteria carried by entomoparasitic nematodes and is investigated as a possible insect biocontrol agent. The recent publication of several genome sequences from bacteria assigned to this species has given rise to inconsistent preliminary results.

Results: The genome of the nematode-derived P. vermicola type strain DSM_17385 has been assembled into a 4.2 Mb sequence comprising 5 scaffolds and 13 contigs. A total of 3969 protein-encoding genes were identified. Multilocus sequence typing with different marker sets revealed that none of the previously published presumed $P$. vermicola genomes represents this taxonomic species. Comparative genomic analysis has confirmed a close phylogenetic relationship of $P$. vermicola to the $P$. rettgeri species complex. P. vermicola DSM_17385 carries a type III secretion system (T3SS-1) with probable function in host cell invasion or intracellular survival. Potentially antibiotic resistance-associated genes comprising numerous efflux pumps and point-mutated house-keeping genes, have been identified across the $P$. vermicola genome. A single small $(3.7 \mathrm{~kb})$ plasmid identified, pPVER1, structurally belongs to the qnrD-type family of fluoroquinolone resistance conferring plasmids that is prominent in Providencia and Proteus bacteria, but lacks the gnrD resistance gene.
\end{abstract}

\footnotetext{
*Correspondence: giuseppe.andolfo@unina.it;

giuseppeandolfo@hotmail.com; andreas.leclerque@tu-darmstadt.de;

leclerque@hotmail.com

'Department of Agricultural Sciences, University of Naples "Federico II", Via

Università 100, 80055 Portici, Italy

${ }^{2}$ Department of Biology, Technische Universität Darmstadt,

Schnittspahnstraße 10, 64287 Darmstadt, Germany

${ }^{3}$ Istituto per la Protezione Sostenibile delle Piante (IPSP), Consiglio Nazionale

delle Ricerche (CNR), Piazzale Enrico Fermi 1, 80055 Portici, Italy
}

(c) The Author(s). 2021 Open Access This article is licensed under a Creative Commons Attribution 4.0 International License, which permits use, sharing, adaptation, distribution and reproduction in any medium or format, as long as you give appropriate credit to the original author(s) and the source, provide a link to the Creative Commons licence, and indicate if changes were made. The images or other third party material in this article are included in the article's Creative Commons licence, unless indicated otherwise in a credit line to the material. If material is not included in the article's Creative Commons licence and your intended use is not permitted by statutory regulation or exceeds the permitted use, you will need to obtain permission directly from the copyright holder. To view a copy of this licence, visit http://creativecommons.org/licenses/by/4.0/. The Creative Commons Public Domain Dedication waiver (http://creativecommons.org/publicdomain/zero/1.0/) applies to the data made available in this article, unless otherwise stated in a credit line to the data. 
Conclusions: The sequence reported represents the first well-supported published genome for the taxonomic species $P$. vermicola to be used as reference in further comparative genomics studies on Providencia bacteria. Due to a striking difference in the type of injectisome encoded by the respective genomes, $P$. vermicola might operate a fundamentally different mechanism of entomopathogenicity when compared to insect-pathogenic Providencia sneebia or Providencia burhodogranariea. The complete absence of antibiotic resistance gene carrying plasmids or mobile genetic elements as those causing multi drug resistance phenomena in clinical Providencia strains, is consistent with the invertebrate pathogen $P$. vermicola being in its natural environment efficiently excluded from the propagation routes of multidrug resistance (MDR) carrying genetic elements operating between human pathogens. Susceptibility to MDR plasmid acquisition will likely become a major criterion in the evaluation of $P$. vermicola for potential applications in biological pest control.

Keywords: Providencia vermicola, Whole genome analysis, Phylogenomics, Entomopathogenicity, Nematode association, Antibiotic resistance, Type III secretion system (T3SS), Biological control

\section{Background}

Gamma-proteobacteria of the genus Providencia (Enterobacterales; Morganellaceae) have been identified in diverse environmental samples as well as in association with both vertebrate and invertebrate animals and humans. Six out of 10 currently recognized Providencia species, namely $P$. rettgeri, $P$. stuartii, $P$. alcalifaciens, $P$. rustigianii, $P$. heimbachae and $P$. huaxiensis [1], were isolated from clinical samples [2-4] and comprise opportunistic human pathogens typically causing diarrhea [5-7] and urinary tract infections [8] that are often clinically complicated by multidrug resistance of the pathogen [9-12]. Moreover, bacteria assigned to the recognized Providencia species $P$. vermicola, $P$. rettgeri, $P$. alcalifaciens, $P$. sneebia, and $P$. burhodogranariaea [1] together with the recently proposed new species $P$. entomophila [13] have been found associated with or pathogenic to insects as honeybees [14], house and blow flies $[15,16]$, the fly-parasitic wasp Nasonia vitripennis [17], and a diverse range of fruit flies [13, 18-23].

The species $P$. vermicola is conspicuous among these as the putative insecticidal agent carried by entomoparasitic nematodes of the genera Steinernema [24], Butlerius [25] or Rhabditis [26]. However, further nematode-associated bacterial entomopathogens were identified as Providencia sp. [27] or P. rettgeri $[28,29]$. The host-vector-pathogen relationship of these Providencia strains is functionally reminiscent of closely related Xenorhabdus and Photorhabdus bacteria (Enterobacterales; Morganellaceae) [30, 31]. A possible contribution of nematode-associated Providencia bacteria to insect biocontrol has been evaluated $[25,28,29]$.

Moreover, $P$. vermicola has been reported to be a fish pathogen [32-34]. Several Providencia species, including $P$. vermicola, $[35,36]$ have been described as remarkably resistant to high concentrations of metals [37-40] and to several types of antibiotics [35, 36, 41]. During the past decade, a multi drug resistance (MDR) phenomenon linked to the spread of integrons carrying antibiotic resistance genes including the New Delhi metallo-lactamase gene ( $n d m 1)$ has gained clinical importance globally. The $n d m 1$ encoded carbapenemase enables pathogenic enterobacteria, including $P$. rettger $i$ and $P$. stuartii, to hydrolyze a wide spectrum of $ß$-lactam antibiotics [41, 42].

An increasing number of Providencia genome sequences have been published during the past decade, including the recent publication of the genomes (i.e. assemblies GCA_014396895.1, GCA_010748935.1 and GCA_016618195.1) of three Providencia strains assigned to the species $P$. vermicola, namely strain G1 isolated from fish in Algeria, strain P8538 obtained from a clinical sample in Congo and strain LLDRA6 isolated from contaminated soil in China [43]. Comparative approaches have been used to explore the genomes of both clinical [44] and insect derived [45] Providencia bacteria. However, the species $P$. vermicola has not been covered by these studies, mainly due to the lack of a reliable reference genome.

This study reports the genome sequence of the nomenclatural type strain Providencia vermicola DSM 17385 and presents the first complete genome analysis for the taxonomic species P. vermicola. Strain DSM 17385 has previously been isolated from infective juveniles of the entomoparasitic nematode Steinernema thermophilum collected in soils at New Delhi, India, and has been recognized as the type strain of a new taxonomic species on the basis of $16 \mathrm{~S}$ rRNA gene comparisons, restriction pattern based ribo-printing, metabolic property analyses, and a DNA-DNA relatedness value of 30\% with respect to the $P$. rettgeri type strain as determined by physical DNA-DNA reassociation [24].

\section{Results \\ General characteristics of the P. vermicola DSM_17385 genome}

The genome of the P. vermicola type strain DSM_17385 was sequenced in this study and assembled into 5 scaffolds and 13 contigs, starting from 765,178 paired-end 
reads (MiSeq $2 \times 250 \mathrm{bp}$ ). Basic genome information is given in Table 1 . The accumulated scaffold and contig length of this assembly is $4.23 \mathrm{Mb}$ (Fig. 1). The GC content, N50, and L50 of the DSM_17385 genome were $41.1 \%, 344,020$ and 5, respectively. Annotation with GLIMMER resulted in 3969 protein-encoding genes, 220 (i.e. app. 6\%) hypothetical proteins and 74 structural RNA encoding genes, more exactly three $5 \mathrm{~S}$ rRNA, one $16 \mathrm{~S}$ rRNA, one $23 \mathrm{~S}$ rRNA, and 69 tRNA genes. As sequence gaps can cause interruption or deletion of ORFs, and as the DSM_17385 genome was not optically mapped, inferred annotations might be incomplete.

We performed a GO-term annotation analysis of all protein-encoding genes identified by GLIMMER. Through this analysis, we were able to assign functional annotations to 3749 (app. 95\%) of the predicted genes (Fig. 2a). Coding sequences were assigned to putative super-functional and functional categories using the clusters of orthologous groups of proteins (COG) database [46]. Approximately $40 \%$ of the predicted genes were dedicated to metabolic functions. One-third was roughly evenly split between cellular process/signaling functions and information storage/ processing functions. Functions of those predicted genes in the remaining $20 \%$ of genome were either poorly categorized or uncategorized (Fig. 2a).

\section{Multilocus sequence typing and phylogenetic reconstruction}

Phylogenetic reconstruction from three independent datasets was performed in order to assess the systematic position of $P$. vermicola DSM_17385. The complete $16 \mathrm{~S}$ ribosomal RNA encoding gene comprising in length 1528 nucleotides was employed at a first level of phylogenetic analysis, extending the previous $16 \mathrm{~S}$ rRNA based

Table 1 Genomic features of P. vermicola strain DSM_17385

\begin{tabular}{ll}
\hline Attribute & Value \\
\hline Sequencing platform & Illumina MiSeq \\
Assembler & SPADES \\
Assembly accession & JAGSPI000000000 \\
Topology & Circular \\
No. of scaffolds/contigs & 18 \\
Genome size (bp) & $4,233,718$ \\
DNA G +C (\%) & 41.1 \\
Genome coverage (X) & 30 \\
Number of RNAs genes & 74 \\
Number of tRNAs genes & 69 \\
N50 & 344,819 \\
L50 & 5 \\
Number of CDSs & 3969 \\
Pseudo genes & 220 \\
\hline
\end{tabular}

phylogenetic analysis [24] to a larger set of reference strains. The second dataset, referred to as "hMLST", was composed of five housekeeping genes encoding translation elongation factor EF-G (fusA), DNA gyrase subunit B (gyrB), isoleucyl-tRNA synthetase (ileS), translation elongation factor EF-4 (lepA), and leucyl-tRNA synthetase (leuS) that have been used previously in molecular taxonomy studies of Providencia bacteria [13, 19]. The third dataset, referred to as "rMLST", comprised the full set of ribosomal rpl, rpm and rps proteins employed in bacterial rMLST approaches [47]. The full coding sequences of the $16 \mathrm{~S}$ rRNA, the five hMLST and 53 rMLST markers were identified in the genome sequence under study (Additional files 1 and 2).

Comparison of the $16 \mathrm{~S}$ rRNA genes from a set of 31 bacterial strains representing the major groups of Providencia bacteria including the nomenclatural type strains of all recognized Providencia species gave rise to a phylogenetic tree (Suppl. Figure 1) generally characterized by insufficiently bootstrap supported clades. $P$. vermicola DSM_17385 together with supposed P. vermicola strain G1 and several strains assigned to the species $P$. rettgeri were grouped together in a clade with branches receiving from 20 to $52 \%$ bootstrap support. The two further supposed P. vermicola strains P8358 and LLDR A6 together with the $P$. sneebia type strain were loosely, i.e. with bootstrap support values between 16 and 43\%, associated to an optimally supported clade comprising all $P$. stuartii strains together with the $P$. thailandensis type strain. Insufficient resolution of $16 \mathrm{~S}$ rRNA phylogenies at the level of Providencia species delineation had already been stated previously $[19,24]$.

Concatenation of the identified hMLST and rMLST marker genes resulted in combined meta-gene sequences comprising 11,619 bp and 21,267 bp in length, respectively. Comparison with the concatenated orthologs from 31 representative Providencia genomes gave rise to phylogenies of essentially identical tree topology (Figs. 3 and 4). In particular, both the hMLST and rMLST based phylogenies coincided i) in placing the $P$. vermicola type strain DSM_17385 into a sister clade position to clades $\mathrm{A}$ and $\mathrm{B}$ of the $P$. rettgeri complex, well delineated from the type strains of all further Providencia species, and ii) in not co-locating the presumed $P$. vermicola whole genome sequences from Providencia strains P8538, LLDRA6 and G1 with the P. vermicola type strain. Whereas Providencia strain G1 was firmly, i.e. with $100 \%$ bootstrap support in both phylogenies, positioned within the $P$. rettgeri clade B, strains P8538 and LLDRA6 appeared loosely related to each other and to an optimally bootstrap supported clade comprising the nomenclatural type strains of both the species $P$. stuartii and $P$. thailandensis. Concerning the systematic position of Providencia strains P8358 and LLDRA6, both these hMLST and rMLST 


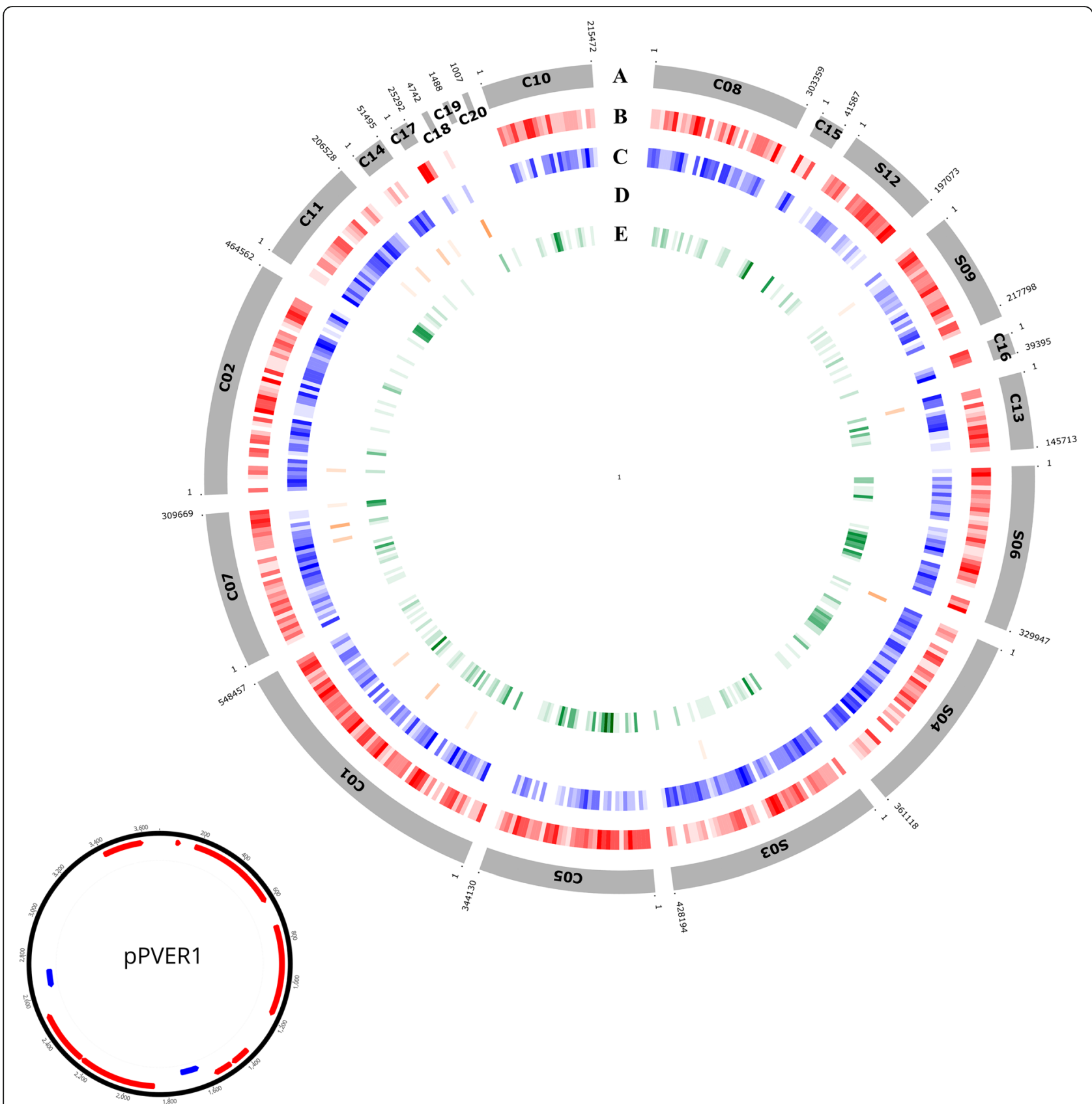

Fig. 1 Circular maps of the P. vermicola DSM_17385 genome (A) and of plasmid PPVER1 (B). A The scaffolds and contigs are ordered and oriented for maximum synteny with the $P$. rettgeri Dmel1 genome sequence. Scaffolds $(S)$ and contigs $(\mathbf{C})$ are not positioned in a complete circle because their order and orientation are not empirically known. The size of the gaps between scaffolds is unknown. Rings from the outermost to the center: genes on the forward strand (red), genes on the reverse strand (blue), tRNA and rRNA genes (orange), genes unique to P. vermicola (green). B Physical map of plasmid pPVER1: ORFs on the forward strand (red), genes on the reverse strand (blue)

phylogenies essentially reproduced the results obtained from $16 \mathrm{~S}$ rRNA gene comparisons.

When phylogenetic reconstruction from the concatenated hMLST marker set was extended to all 195 Providencia genomes currently available in the Genbank database (Suppl. Figure S2), both strains P8358 and LLDRA6 formed 100\% bootstrap supported clades with a small number of strains assigned to the species $P$. stuartii. However, these clades were well delineated from the "main" P. stuartii clade comprising at $100 \%$ bootstrap support the vast majority of all strains assigned to this species together with the nomenclatural type strains of both $P$. stuartii and $P$. thailandensis.

Ribosomal typing of $P$. vermicola DSM_17385 and the three presumed $P$. vermicola genome strains gave rise to 


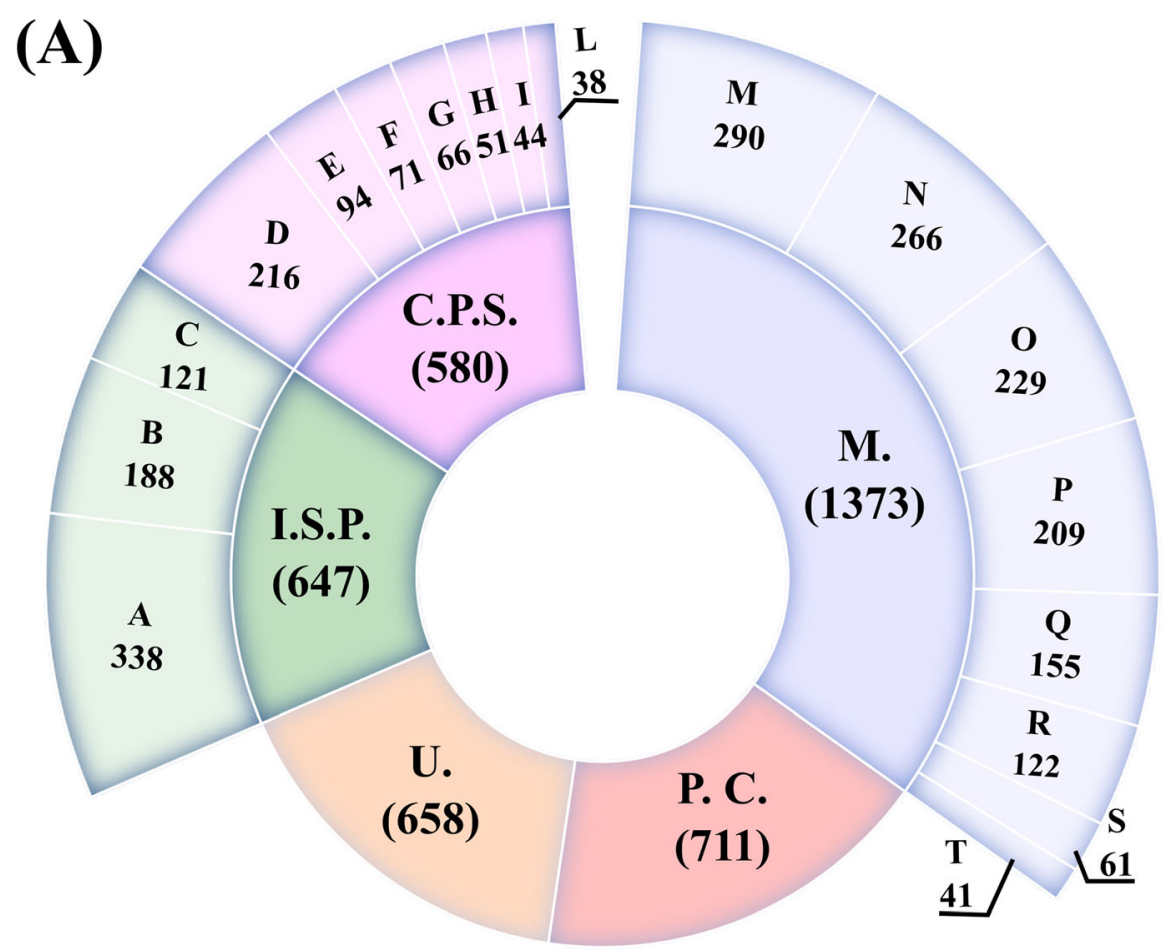

(B)
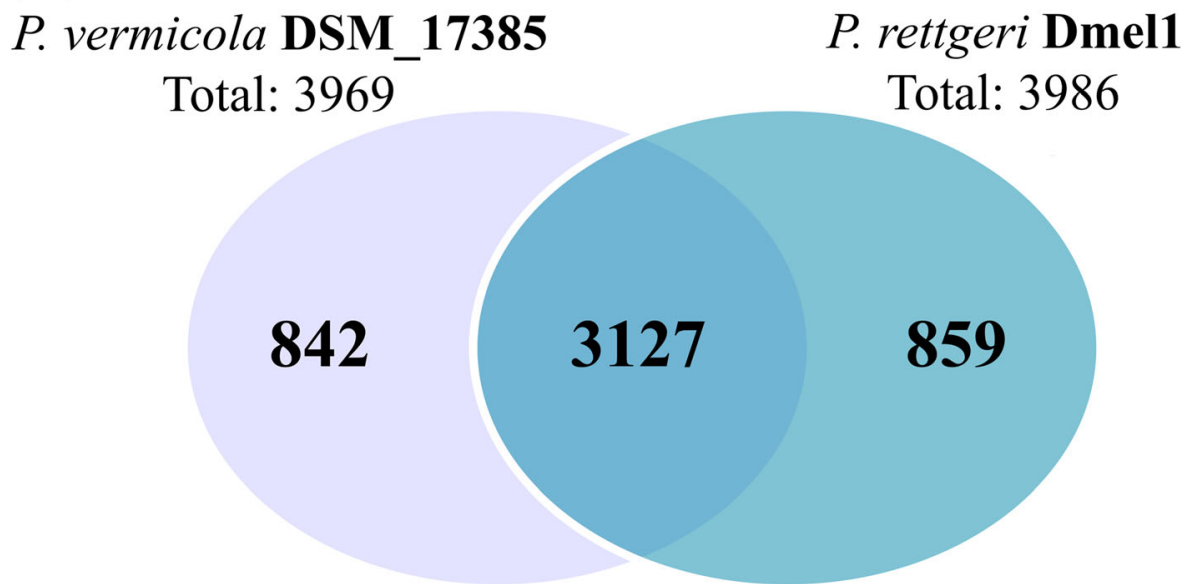

Fig. 2 Functional annotation of $P$. vermicola DSM_17385 genes. A COG categories of predicted $P$. vermicola genes on the inner and COG subcategories on the outer ring. Each category or subcategory is graphed as a percentage of the total number of genes. M.: metabolism; P.C:: poorly characterized; U.: uncharacterized; I.S.P.: information storage and processing; C.P.S.: cellular processes and signaling. B Numbers of shared and unique protein-encoding genes when comparing $P$. vermicola DSM_17385 to P. rettgeri Dmel1. Numbers are the gene counts within each sector of the Venn diagram

highly diverse rMLST based taxonomic assignments (Table 2). When compared to the PubMLST ribosomal protein encoding gene database, exactly matching alleles were identified for only five out of the 53 rMLST marker genes identified in the $P$. vermicola type strain genome, providing a too scarce statistical basis for reliable ribosomal sequence type (rST) assignment. The rMLST based taxonomic assignment to either $P$. rettgeri or $P$. burhodogranariea remained ill-supported and inconclusive.
Ribosomal typing of Providencia strain P8538, in contrast, resulted in an apparently highly conclusive outcome, with 53/53 exact allele matches giving rise to an unequivocal rST identification and a maximally supported taxonomic assignment to the species $P$. vermicola. However, as the P8538 genome currently serves as reference for the species $P$. vermicola in the PubMLST database, these results cannot be judged meaningful. On the basis of ribosomal typing, presumed $P$. vermicola 


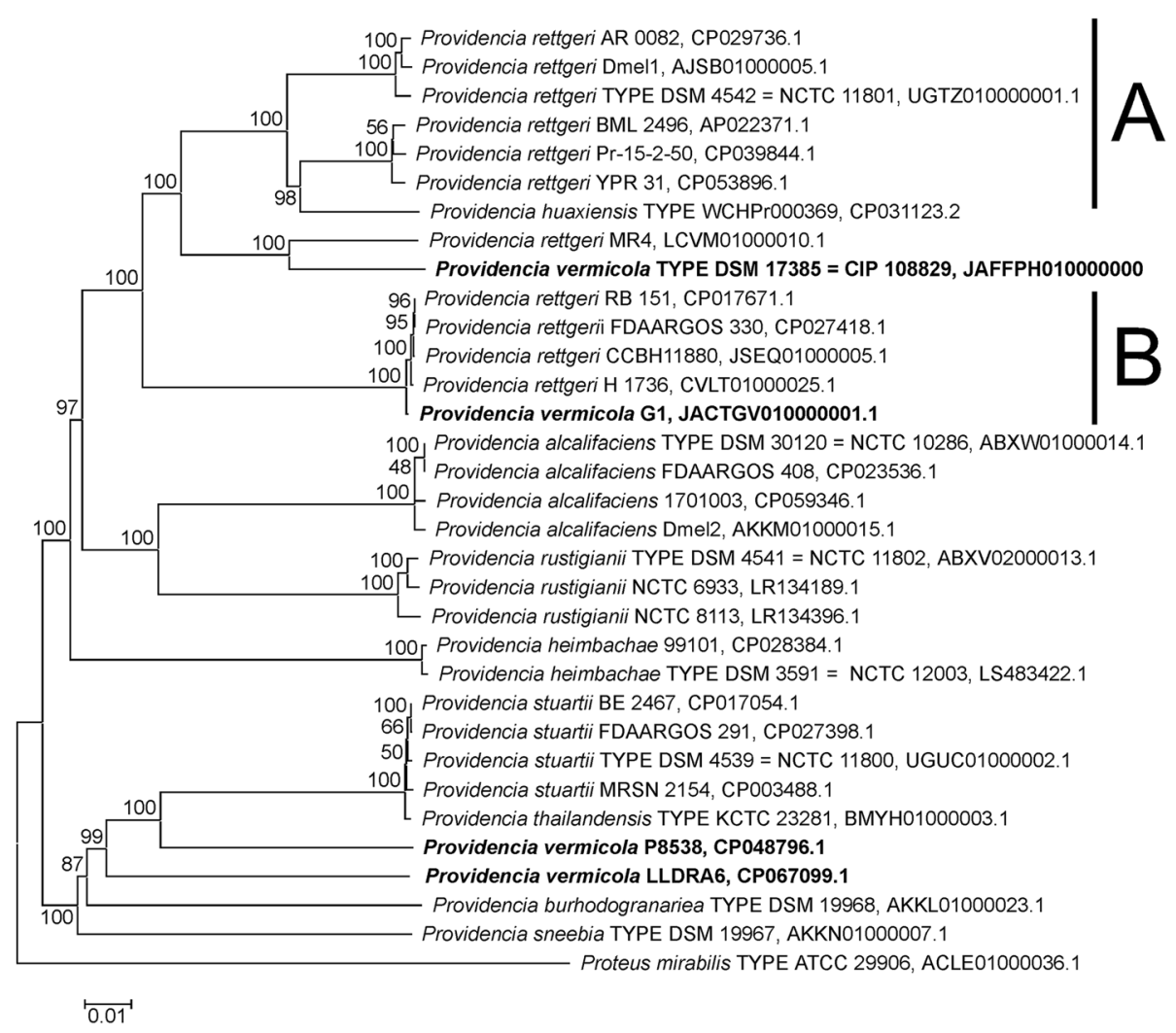

Fig. 3 Neighbor Joining (NJ) phylogeny of Providencia bacteria as reconstructed from concatenated complete fus A, gyrB, iles, lepA and leuS gene sequences. Terminal branches are labelled by genus, species and strain designations as well as GenBank accession numbers; "TYPE" indicates nomenclatural type strains of the respective taxonomic species. Bacterial strains that have been assigned to the species $P$. vermicola are in bold type. Numbers on branches indicate bootstrap support percentages. P. rettgeri clades A and B are indicated at the right margin. The size bar corresponds to $1 \%$ sequence divergence; the length of dashed lines is not true to scale. The concatenation of orthologous sequences from the closely related bacterium Proteus mirabilis has been used as outgroup

strains LLDRA6 and G1 were assigned with low to intermediate support to the species $P$. stuartii and $P$. rettgeri (clade B), respectively (Table 2 ).

Phylogenetic reconstruction based on the concatenated hMLST marker set from the 195 Providencia genomes available in the Genbank database demonstrated that $P$. vermicola DSM_17385 appears molecular taxonomically most closely related to a single genome strain, namely Providencia strain MR4 that has previously been assigned to the species $P$. rettgeri (Suppl. Figure S2). In both the concatenated hMLST and rMLST marker based phylogenies P. vermicola DSM_17385 and strain MR4 form a maximally bootstrap supported clade with comparatively long branches indicating considerable sequence divergence (Figs. 3 and 4). However, orthologs of only $4 / 5$ hMLST markers (all but gene lepA) and 50/53 rMLST markers (all but genes rplM, rpsI and $r p s L$ ) were identified in the published MR4 genome sequence. With respect to the hMLST data set, the respective clade was supported in the gyrB, ileS and leuS, but not in the the fusA single marker phylogenies. With respect to the rMLST data set, the p-distance matrix based pair-wise sequence similarity for the concatenation of 50 rMLST marker alleles from strains DSM_17385 and MR4 was calculated to be $97.8 \%$. This corresponded to the pair-wise sequence similarities of the $P$. vermicola type strain to the $P$. rettgeri (clade A) type strain DSM_4542 (97.9\%), the $P$. huaxiensis type strain WCHPr000369 (97.8\%) or strains making up $P$. rettgeri clade B (range 97.4 - 97.5\%) with sequence similarities to the type strains representing further Providencia species being $97.0 \%$ ( $P$. alcalifaciens) or considerably lower (Suppl. Table S1). In contrast, sequence similarities within $P$. rettgeri clades A and B were generally superior to $99 \%$. However, analogous pairwise sequence similarity percentages calculated from the hMLST data set are consistent with a comparatively closer phylogenetic relationship of P. vermicola DSM_17385 and strain MR4 (Suppl. Table S1). Ribosomal typing of Providencia strain MR4 identified 49/50 exact matches and gave rise to a maximally supported taxonomic assignment to the species $P$. rettgeri and to three $\mathrm{rST}$ representing this species (Table 2). 


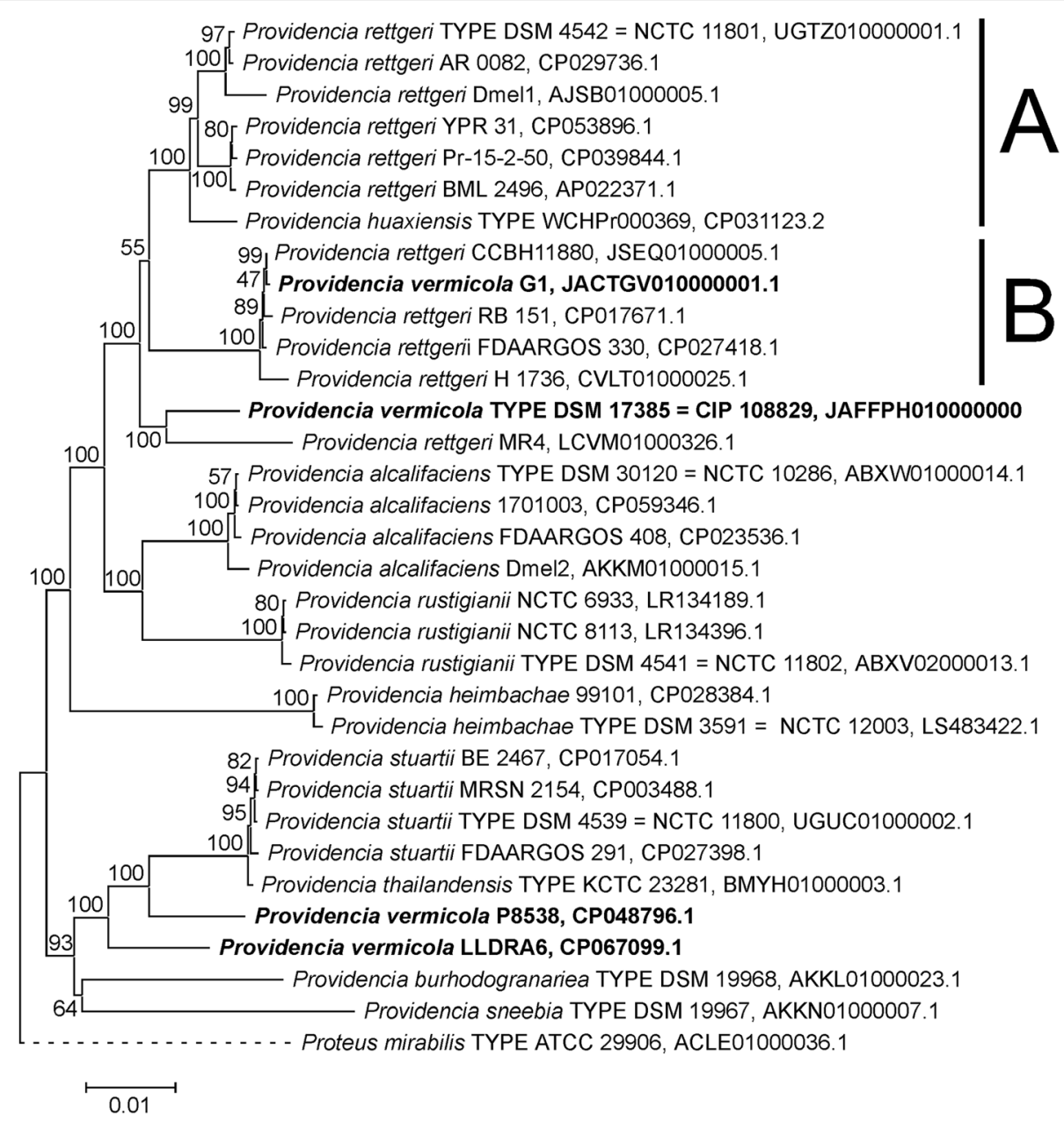

Fig. 4 Neighbor Joining (NJ) phylogeny of Providencia bacteria as reconstructed from 53 concatenated ribosomal protein encoding genes. Terminal branches are labelled by genus, species and strain designations as well as GenBank accession numbers; "TYPE" indicates nomenclatural type strains of the respective taxonomic species. Bacterial strains that have been assigned to the species $P$. vermicola are in bold type. Numbers on branches indicate bootstrap support percentages. P. rettgeri clades A and B are indicated at the right margin. The size bar corresponds to $1 \%$ sequence divergence; the length of dashed lines is not true to scale. The concatenation of orthologous sequences from the closely related bacterium Proteus mirabilis has been used as outgroup

\section{Digital DNA-DNA hybridization analysis}

Among the methods for evolutionary distance assessment between bacterial species based on digital whole genome comparison, average nucleotide identity (ANI) is one of the most powerful approaches [48]. Therefore, pair-wise genome-wide average nucleotide identity by orthology (OrthoANI) has been determined for two subsets of 10 Providencia strains. The main results obtained were as follows (Fig. 5): i) pair-wise ANI values for the $P$. vermicola DSM_17385 genome and one of the nine

Table 2 rMLST results for presumed $P$. vermicola genome sequencing strains

\begin{tabular}{lllll}
\hline Strain designation & $\begin{array}{l}\text { Type } \\
\text { strain }\end{array}$ & Exact allele matches & $\begin{array}{l}\text { Number of rST assigned } \\
\text { (Mismatch threshold appl.) }\end{array}$ & $\begin{array}{l}\text { rMLST based assignment } \\
\text { (support level) }\end{array}$ \\
\hline DSM_17385 & Yes & $5 / 53$ & 0 (n.a.) & $\begin{array}{l}\text { P. rettgeri (75\%) } \\
\text { P. burhodogranariea (25\%) }\end{array}$ \\
G1 & No & $41 / 52$ & $12(20)$ & P. rettgeri (92\%) \\
LLDRA6 & No & $53 / 53$ & $3(20)$ & P. stuartii (79\%) \\
P8538 & No & $53 / 53$ & $1(1-5)$ & P. vermicola (100\%) \\
MR4 & No & $49 / 50$ & $3(20)$ & P. rettgeri (100\%) \\
\hline
\end{tabular}


Providencia type strains representing one of the further recognized species ranged between 77 and $81 \%$, i.e. were in the range of values normally found for pair-wise ANI percentages across this set of specific type strains; ii) pair-wise ANI values for comparisons of strain DSM 17385 with one of the three further supposed P. vermicola strains G1, P8538 and LLDRA6 were in this same range, more exactly $81 \%$ for strain G1 and $77 \%$ for both strains P8538 and LLDRA6; iii) pair-wise ANI values for comparisons of supposed P. vermicola strains G1, P8538 and LLDRA6 and Providencia strains assigned to other species were found to be considerably higher than the above percentage range as, for instance, in the order of magnitude of $99 \%$ for the pair-wise comparisons of strain G1 with $P$. rettgeri strain RB151 (representing $P$. rettgeri clade B), of strain $\mathrm{P} 8358$ with $P$. stuartii strain PRV00010, and of strain LLDRA6 with $P$. stuartii strain Crippen.

Under the assumption that ANI values of $95-96 \%$ indicate bacterial species boundaries [49], these results are consistent with the following statements: i) P. vermicola strain DSM_17385 is not more closely related to any of the other specific type strains recognized within the genus Providencia as the latter are among each other and is, therefore, correctly considered type strain of an independent species; ii) none of the three supposed $P$. vermicola strains G1, P8358 and LLDRA6 belongs to the same species as the $P$. vermicola type strain; iii) instead, Providencia strains G1, P8358 and LLDRA6 should at the species level be assigned to the same taxon as strains P. rettgeri RB151, P. stuartii PRV00010 and P. stuartii Crippen, respectively.

\section{Comparative genomic analysis}

A comparative genomics approach was employed to identify orthologous proteins in P. vermicola DSM 17385 and the insect-derived $P$. rettgeri (clade A) strain Dmel1. Dmel1 has been originally isolated from wildcaught Drosophila melanogaster and has been demonstrated to be a fruit fly pathogen [20]. Moreover, the genome of strain Dmel1 is well annotated and has been compared to genomes of fruit fly associated Providencia strains falling under the species $P$. alcalifaciens, $P$. sneebia, and P. burhodogranariea [45].

Based on this comparison, 3127 bona fide orthologous pairs were identified (Fig. 2b) with the large majority being present as single copies. This core genome is $78 \%$ of the total genes identified in each genome alone, and the corresponding orthologous gene pairs were distributed over $86 \%$ of the $P$. vermicola and $83 \%$ of the $P$. rettgeri genome. The corresponding genes together covered an analyzed genomic region of $3.6 \mathrm{Mb}$ in both $P$. vermicola

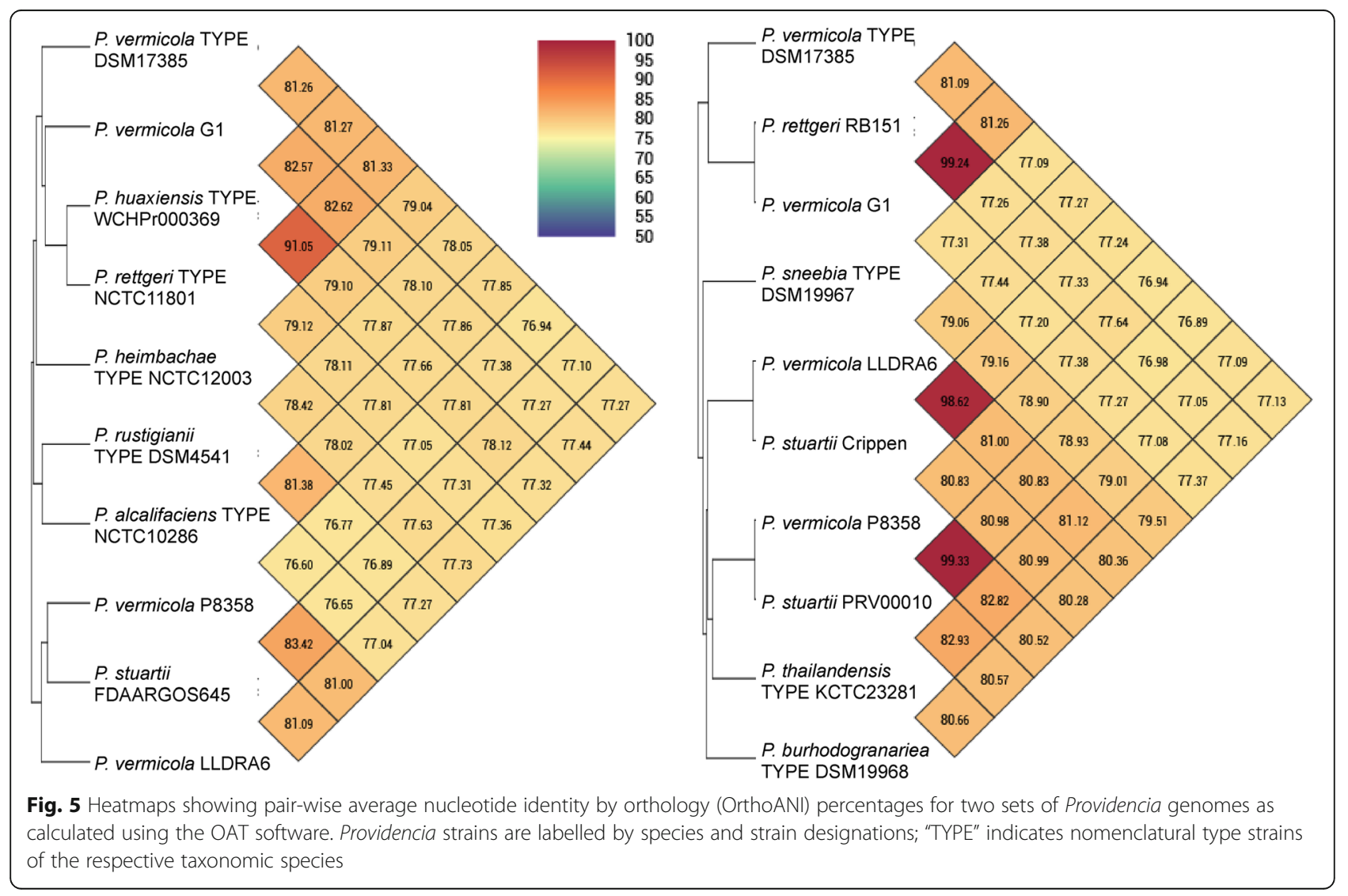


and $P$. rettgeri. The absolute number of unique genes, i.e. those not assigned to any orthologous pair, was very similar in both genomes, with 847 and 859 unique genes being detected in $P$. vermicola and $P$. rettgeri, respectively (Fig. 2b). Thus, unique single-copy genes represent app. $21 \%$ of the total genome content for both species.

The scaffolds and contigs of DSM_17385 were ordered and oriented so that they were as similar to the $P$. rettgeri Dmel1 genomic orientations as possible, assuming the most parsimonious evolution of genome arrangements. The global identity estimated from LASTZ was 82.3\% (Fig. 6a). Genomic rearrangements are highlighted on the physical synteny map reported in Fig. 6b. It is in principle possible that any of the $P$. vermicola contigs could be inverted or rearranged relative to their positions on our comparative syntenic plot, but only if the rearrangement breakpoints lie at contig breakpoints.

The genomic rearrangements associated with speciation of $P$. vermicola and $P$. rettgeri from a common ancestor have partially preserved the location and organization of several homologous genomic regions. A total of 15 collinear blocks were discovered and identified between P. vermicola and P. rettgeri genomes (Fig. 6b). Many small rearrangements and two larger inversions were apparent across both genomes, the latter (in red Fig. 6a) involving a genomic region of app. $16 \mathrm{~kb}$ on contig 8. In particular, a large genomic inversion of app. $800 \mathrm{~kb}$ including a type III secretion system (T3SS1 ) encoding gene cluster that has been identified previously in $P$. sneebia [45] is syntenically oriented in the $P$. vermicola genome with respect to $P$. rettgeri Dmell.

\section{Type III secretion systems}

A single gene cluster encoding a type III secretion system (T3SS) or "injectisome", i.e. a needle-like apparatus involved in protein secretion across a host cell membrane, was identified in the P. vermicola DSM_17385 genome. The cluster comprising $22 \mathrm{~kb}$ and 23 ORFs was highly similar (app. $65 \%$ of pairwise identity) in gene orientation and putative gene function to a T3SS-1 island of P. rettgeri Dmel1 (Fig. 7); in particular, both clusters comprised a gene encoding an InvA-type ATPase and were located in a region of synteny that is inversed in P. sneebia. In contrast, no region of significant similarity to a second T3SS-2 island comprising a Ysc-type ATPase gene that is present in insect-associated $P$. sneebia and $P$. burhodogranariea bacteria, was identified in the genome sequence under study.

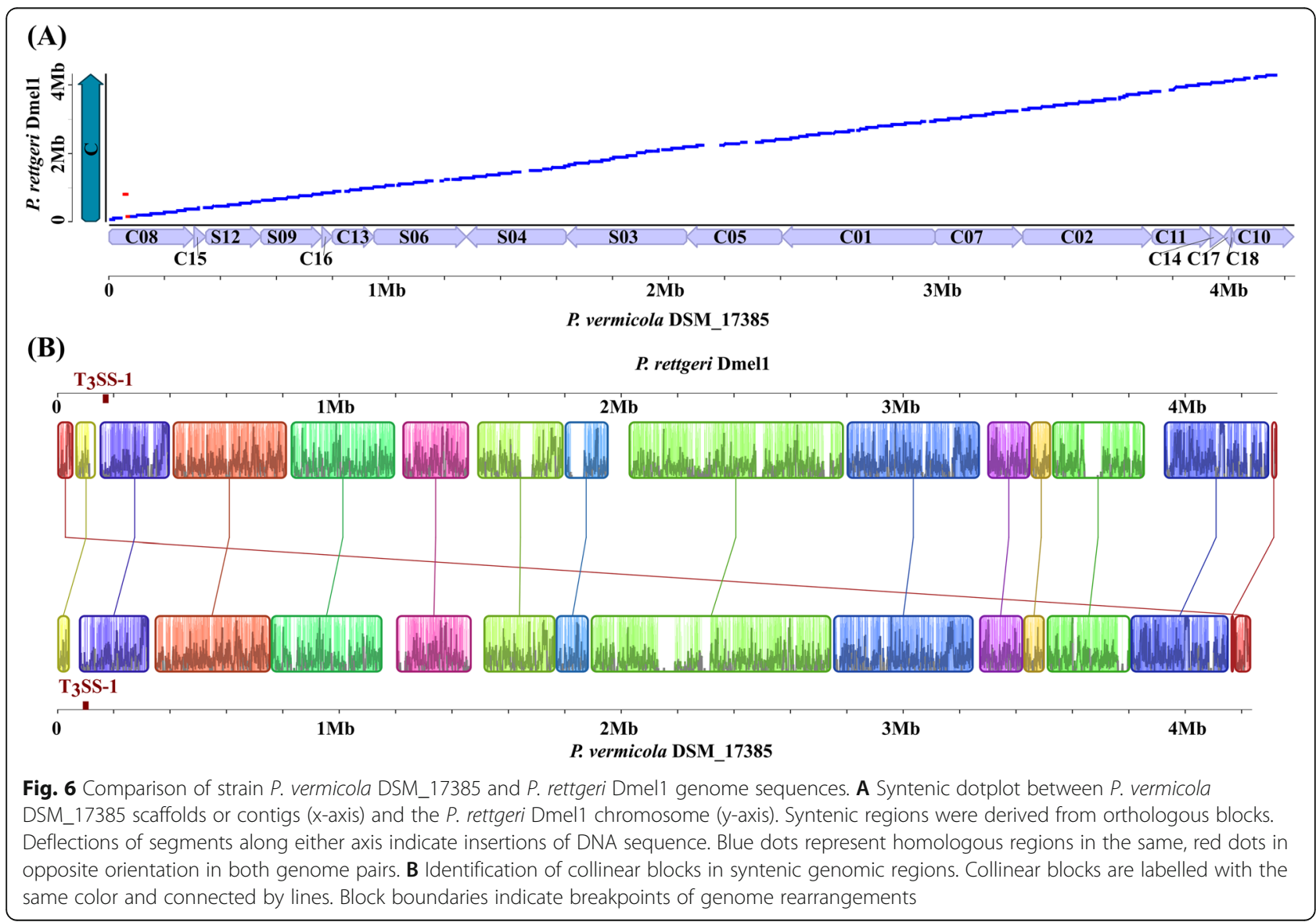




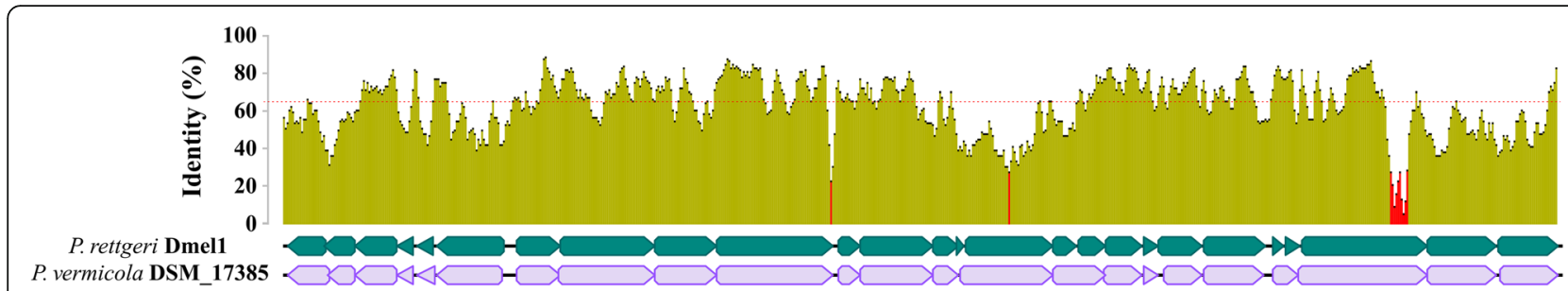

Fig. 7 Alignment of type III secretion systems (T3SS-1) of P. vermicola DSM_17385 and P. rettgeri Dmel1. The graph shows the pairwise identity (sliding windows size of 100 nucleotide) between T3SS-1 sequences. Average pairwise identity across the full length sequence (64.5\%) is indicated by the dashed red line. Colored arrows indicate individual genes and their orientation. The aligned genomic regions indicate the approximate boundaries of the T3SS-1 islands based on gene annotation

\section{Plasmids}

No sequences corresponding to the $5.6 \mathrm{~kb}$ plasmid pPRET1 previously detected in $P$. rettgeri Dmel1 or to the plasmids known from other $D$. melanogaster associated Providencia species [45] nor to the multi-drug resistance plasmids of $P$. rettgeri and $P$. stuartii [50] were identified in the $P$. vermicola DSM_17385 genome. However, one small non-transmissible plasmid was identified. pPVER1 comprised in length $3682 \mathrm{bp}$ and contained 10 ORFs (Fig. 1b). ORF2, ORF3 and ORF4 encoded hypothetical proteins comprising deduced sequences of, respectively, 66, 146, and 147 amino acids with $>90 \%$ similarity to gene products encoded by a family of $q n r D$-carrying plasmids that have been described previously for several strains of $P$. rettgeri (plasmids pDIJ09-518a, pGHS09-09a, pAB213, pYPR25-3), P. stuartii (pMF1A) and P. alcalifaciens (pBT169) and further Morganellaceae bacteria [51] as well as to (partially truncated) gene products encoded by plasmid p3000369 of $P$. huaxiensis [4]. ORF1b of pPVER1 encoded a hypothetical protein of 88 amino acids with lower similarity to presumed orthologs in the genomes of Klebsiella, Enterobacter and Citrobacter bacteria (app. $60 \%$ similarity) and of sporadic presence in genomes of several P. rettgeri (51\%), P. alcalifaciens (51\%), P. stuartii (39\%) and P. heimbachae (37\%) strains, whereas the partially overlapping ORF1a encoded a hypothetical gene product of 170 amino acids with no significant similarities identified across the Genbank database. Moreover, five short (<100 bp) ORFs named ORF5 through ORF9 with no significant similarity hits across Genbank were found located up- and downstream of ORF1a/b. Two 24 bp imperfect inverted repeats with eight mismatches delineated the region comprising colinear ORF1a, ORF1b and ORF2 and consistently defined a mobile insertion cassette (mic) of $2663 \mathrm{bp}$ bracketed by both copies of a presumed duplicated CA insertion site.

\section{Antibiotic resistance genes}

Antibiotic resistance factors encoded in the $P$. vermicola DSM_17385 genome operate by four resistance mechanisms with antibiotic efflux being the predominant one, followed by antibiotic target alteration, antibiotic inactivation and reduced antibiotic uptake (Table 3, Suppl. Table S2, Additional file 3).

Among the different types of efflux pumps identified, orthologs of the SMR-type efflux pump EmrE [52], the peptide-potassium antiporter RosAB [53], the MFS-type efflux pumps MdtG [54], KpnEF [55] and KpnGH-TolC $[56,57]$ as well as the ABC-type transporter MacABTolC $[58,59]$ are ubiquitously distributed across the genus Providencia, whereas the SMR-type efflux pump AbeS [60] potentially confers macrolide and aminocoumarin resistance to Providencia bacteria belonging to the species $P$. stuartii and $P$. rettgeri clade A and the MFS-type transporter Tet (59) [61] is mainly responsible for widespread tetracycline resistance observed in $P$. rettgeri, $P$. alcalifaciens and $P$. heimbachae bacteria [44]. Further identified efflux pump orthologs as the TolCdependent transporters MdtABC [62], AcrAB [63] and EmrAB [64], the OpmD-dependent RND-type pump MexGHI [65], the MFS-type systems MdtH [66] and Bcr1/2 [67] appear sporadically across the genus Providencia. The identified ortholog of the transcriptional acr $A B$ operon repressor AcrR [68] has been found to carry two known (Y114F, V165I) and one previously undescribed (M109L) mutations potentially conferring or increasing resistance to a spectrum of antibiotics including tetracycline, phenicols, penam, triclosan and fluoroquinolones [69]. Orthologs of further potentially resistance-relevant regulators as the carbon storage regulator protein CsrA [70, 71] and the cAMP-activated global transcriptional repressor CRP [72] have expectedly been identified, but will most likely not have an immediate role in antibiotic resistance regulation in $P$. vermicola as their known respective targets, i.e. the efflux pumps MexEF-OprN [73] and MdtEF [74, 75], respectively, are lacking. Moreover, an ortholog of the alternative porin OmpK37 [76] that reduces permeability of the cell envelope for a range of beta-lactams and is present in almost all sequenced Providencia genomes [44], has been identified in P. vermicola. 
Table 3 Putative antibiotic resistance-associated factors (ARF) encoded by the P. vermicola DSM_17385 genome

\begin{tabular}{|c|c|c|c|c|}
\hline $\begin{array}{l}\text { ARF } \\
\text { Acronym }\end{array}$ & ARF Family ${ }^{a}$ & $\begin{array}{l}\text { Best } \\
\text { hit }^{\mathrm{b}} \\
\text { CARD }\end{array}$ & $\begin{array}{l}\text { Best hit } \\
\text { Genbank }\end{array}$ & Antibiotic class \\
\hline \multicolumn{5}{|c|}{ Antibiotic uptake reduction } \\
\hline OmpK37 & porin & $\begin{array}{l}56 \% \\
(98 \%)\end{array}$ & $\begin{array}{l}91 \% \\
(100 \%)\end{array}$ & cephamycin, penem, monobactam, penam, cephalosporin, carbapenem \\
\hline \multicolumn{5}{|c|}{ Antibiotic efflux } \\
\hline Abes & SMR & $\begin{array}{l}48 \% \\
(100 \%)\end{array}$ & $\begin{array}{l}89 \% \\
(100 \%)\end{array}$ & macrolides, aminocoumarin \\
\hline CRP & transcriptional regulator & $\begin{array}{l}98 \% \\
(78 \%)\end{array}$ & $\begin{array}{l}100 \% \\
(100 \%)\end{array}$ & penam, macrolide, fluoroquinolone \\
\hline $\begin{array}{l}\text { CsrA } \\
\text { (RsmA) }\end{array}$ & RND & $\begin{array}{l}88 \% \\
(100 \%)\end{array}$ & $\begin{array}{l}100 \% \\
(100 \%)\end{array}$ & phenicol, diaminopyrimidine, fluoroquinolone \\
\hline $\begin{array}{l}\text { Bcr1 } \\
\text { (Bcr1) }\end{array}$ & MFS & $\begin{array}{l}44 \% \\
(100 \%)\end{array}$ & $\begin{array}{l}93 \% \\
(100 \%)\end{array}$ & bicyclomycinsulfonamid \\
\hline $\begin{array}{l}\mathrm{Bcr} 1 \\
(\mathrm{Bcr} 2 / 3)\end{array}$ & MFS & $\begin{array}{l}34 \% \\
(98 \%)\end{array}$ & $\begin{array}{l}98 \% \\
(100 \%)\end{array}$ & bicyclomycin \\
\hline EmrE2 & SMR & $\begin{array}{l}54 \% \\
(100 \%)\end{array}$ & $\begin{array}{l}90 \% \\
(100 \%)\end{array}$ & $\begin{array}{l}\text { macrolides, small polyaromatic cations, potentially ethidium bromide, } \\
\text { erythromycinE. coli, tetraphenylphosphonium, methyl viologen, gentamicin, } \\
\text { kanamycin, neomycin }\end{array}$ \\
\hline $\begin{array}{l}\text { MdtG } \\
\text { (YceE) }\end{array}$ & MFS & $\begin{array}{l}70 \% \\
(100 \%)\end{array}$ & $99 \%(98 \%)$ & phosphomycin, deoxycholate \\
\hline $\mathrm{MdtH}$ & MFS & $\begin{array}{l}75 \% \\
(100 \%)\end{array}$ & $\begin{array}{l}98 \% \\
(100 \%)\end{array}$ & fluoroquinolone \\
\hline Tet(59) & MFS & $\begin{array}{l}81 \% \\
(100 \%)\end{array}$ & $79 \%(97 \%)$ & tetracycline \\
\hline TolC & outer membrane efflux protein & $\begin{array}{l}65 \% \\
(97 \%)\end{array}$ & $95 \%(99 \%)$ & $\begin{array}{l}\text { macrolide, fluoroquinolone, aminoglycosides, carbapenem, cephalosporin, } \\
\text { glycylcycline, cephamycin, penam, tetracycline, peptide antibiotics, } \\
\text { aminocoumarin, rifamycin, phenicol, triclosan, penem }\end{array}$ \\
\hline AcrA & RND & $\begin{array}{l}67 \% \\
(98 \%)\end{array}$ & $95 \%(95 \%)$ & $\begin{array}{l}\text { fluoroquinolone, cephalosporin, glycylcycline, penam, tetracycline, rifamycin, } \\
\text { phenicols, triclosan }\end{array}$ \\
\hline AcrB & RND & $\begin{array}{l}75 \% \\
(98 \%)\end{array}$ & $\begin{array}{l}98 \% \\
(100 \%)\end{array}$ & $\begin{array}{l}\text { fluoroquinolone, cephalosporin, glycylcycline, penam, tetracycline, rifamycin, } \\
\text { phenicols, triclosan }\end{array}$ \\
\hline AcrR & transcriptional regulator & $\begin{array}{l}52 \% \\
(100 \%)\end{array}$ & $94 \%(99 \%)$ & $\begin{array}{l}\text { fluoroquinolone, cephalosporin, glycylcycline, penam, tetracycline, rifamycin, } \\
\text { phenicols, triclosan }\end{array}$ \\
\hline EmrA & MFS & $\begin{array}{l}56 \% \\
(100 \%)\end{array}$ & $\begin{array}{l}94 \% \\
(100 \%)\end{array}$ & fluoroquinolone, nalidixic acid, thiolactomycin \\
\hline EmrB & MFS & $\begin{array}{l}66 \% \\
(99 \%)\end{array}$ & $99 \%(99 \%)$ & fluoroquinolone, nalidixic acid, thiolactomycin \\
\hline $\begin{array}{l}\text { MacA } \\
(\text { PvdR })\end{array}$ & $A B C$ & $\begin{array}{l}37 \% \\
(94 \%)\end{array}$ & $90 \%(97 \%)$ & macrolideserythromycin \\
\hline $\begin{array}{l}\text { MacB } \\
(\mathrm{PvdT})\end{array}$ & $A B C$ & $\begin{array}{l}51 \% \\
(100 \%)\end{array}$ & $\begin{array}{l}89 \% \\
(100 \%)\end{array}$ & macrolideserythromycin \\
\hline $\begin{array}{l}\text { MdtA } \\
\text { (YegM) }\end{array}$ & RND & $\begin{array}{l}57 \% \\
(100 \%)\end{array}$ & $\begin{array}{l}91 \% \\
(100 \%)\end{array}$ & aminocoumarin, novobiocin \\
\hline $\begin{array}{l}\text { MdtB } \\
(\text { YegN) }\end{array}$ & RND & $\begin{array}{l}77 \% \\
(99 \%)\end{array}$ & $\begin{array}{l}94 \% \\
(100 \%)\end{array}$ & aminocoumarin, novobiocin \\
\hline $\begin{array}{l}\mathrm{MdtC} \\
(\mathrm{YegO})\end{array}$ & RND & $\begin{array}{l}73 \% \\
(100 \%)\end{array}$ & $\begin{array}{l}95 \% \\
(100 \%)\end{array}$ & aminocoumarin, novobiocin \\
\hline MexG & RND & $\begin{array}{l}63 \% \\
(96 \%)\end{array}$ & $\begin{array}{l}92 \% \\
(100 \%)\end{array}$ & fluoroquinolone, tetracycline, acridine, vanadium, norfloxacin, acriflavin \\
\hline MexH & RND & $\begin{array}{l}58 \% \\
(96 \%)\end{array}$ & $\begin{array}{l}93 \% \\
(100 \%)\end{array}$ & fluoroquinolone, tetracycline, acridine, vanadium, norfloxacin, acriflavin \\
\hline Mexl & RND & $\begin{array}{l}78 \% \\
(100 \%)\end{array}$ & $\begin{array}{l}96 \% \\
(100 \%)\end{array}$ & fluoroquinolone, tetracycline, acridine, vanadium, norfloxacin, acriflavin \\
\hline
\end{tabular}


Table 3 Putative antibiotic resistance-associated factors (ARF) encoded by the P. vermicola DSM_17385 genome (Continued)

\begin{tabular}{|c|c|c|c|c|}
\hline $\begin{array}{l}\text { ARF } \\
\text { Acronym }\end{array}$ & ARF Family ${ }^{a}$ & $\begin{array}{l}\text { Best } \\
\text { hit }^{\mathrm{b}} \\
\text { CARD }\end{array}$ & $\begin{array}{l}\text { Best hit } \\
\text { Genbank }\end{array}$ & Antibiotic class \\
\hline $\begin{array}{l}\text { KpnE } \\
\text { (MdtJ) }\end{array}$ & SMR & $\begin{array}{l}64 \% \\
(100 \%)\end{array}$ & $\begin{array}{l}95 \% \\
(100 \%)\end{array}$ & $\begin{array}{l}\text { macrolides, aminoglycosides, cephalosporin, tetracycline, peptide antibiotics, } \\
\text { rifamycin }\end{array}$ \\
\hline $\begin{array}{l}\text { KpnF } \\
(\mathrm{Mdtl})\end{array}$ & SMR & $\begin{array}{l}71 \% \\
(100 \%)\end{array}$ & $99 \%(82 \%)$ & $\begin{array}{l}\text { macrolides, aminoglycosides, cephalosporin, tetracycline, peptide antibiotics, } \\
\text { rifamycin }\end{array}$ \\
\hline $\begin{array}{l}\text { KpnG } \\
(E m r A)\end{array}$ & MFS & $\begin{array}{l}65 \% \\
(100 \%)\end{array}$ & $\begin{array}{l}92 \% \\
(100 \%)\end{array}$ & $\begin{array}{l}\text { peptide antibiotics, carbapenem, macrolides, cephalosporin, } \\
\text { aminoglycosides, penam, fluoroquinolones, penem, nalidixic acid, } \\
\text { thiolactomycin }\end{array}$ \\
\hline $\begin{array}{l}\mathrm{KpnH} \\
(\mathrm{EmrB})\end{array}$ & MFS & $\begin{array}{l}78 \% \\
(99 \%)\end{array}$ & $98 \%(99 \%)$ & $\begin{array}{l}\text { peptide antibiotics, carbapenem, macrolides, cephalosporin, } \\
\text { aminoglycosides, penam, fluoroquinolones, penem, nalidixic acid, } \\
\text { thiolactomycin }\end{array}$ \\
\hline RosA & MFS & $\begin{array}{l}75 \% \\
(99 \%)\end{array}$ & $\begin{array}{l}96 \% \\
(100 \%)\end{array}$ & peptide antibioticspolymyxin B, fosmidomycin \\
\hline RosB & MFS & $\begin{array}{l}69 \% \\
(100 \%)\end{array}$ & $\begin{array}{l}99 \% \\
(100 \%)\end{array}$ & peptide antibioticspolymyxin $B$, fosmidomycin \\
\hline \multicolumn{5}{|c|}{ Antibiotic inactivation } \\
\hline $\begin{array}{l}\text { AAC(2)- } \\
\text { la }\end{array}$ & aminoglycoside acetyltransferase & $\begin{array}{l}70 \% \\
(87 \%)\end{array}$ & $\begin{array}{l}72 \% \\
(100 \%)\end{array}$ & aminoglycosides \\
\hline Catlll & chloramphenicol acetyltransferase & $\begin{array}{l}56 \% \\
(100 \%)\end{array}$ & $\begin{array}{l}71 \% \\
(100 \%)\end{array}$ & phenicols \\
\hline FosA7.5 & phosphomycin thiol transferase & $\begin{array}{l}62 \% \\
(98 \%)\end{array}$ & $\begin{array}{l}74 \% \\
(100 \%)\end{array}$ & phosphomycin \\
\hline NmcR & transcriptional regulator & $\begin{array}{l}56 \% \\
(99 \%)\end{array}$ & $\begin{array}{l}89 \% \\
(100 \%)\end{array}$ & penam, cephalosporin, cephamycin, carbapenem \\
\hline SRT-2 & beta-lactamase & $\begin{array}{l}56 \% \\
(100 \%)\end{array}$ & $86 \%(99 \%)$ & cephalosporins \\
\hline \multicolumn{5}{|c|}{ Antibiotic target alteration } \\
\hline EF-Tu ${ }^{c}$ & translation elongation factor Tu & $\begin{array}{l}95 \% \\
(74 \%)\end{array}$ & $\begin{array}{l}99 \% \\
(100 \%)\end{array}$ & pulvomycin-class of elfamycins \\
\hline $\begin{array}{l}\text { ErmX, } \\
(\text { Erm34) }\end{array}$ & RNA methyltransferase & $\begin{array}{l}29 \% \\
(95 \%)\end{array}$ & $\begin{array}{l}98 \% \\
(100 \%)\end{array}$ & aminoglycosides \\
\hline GyrA & DNA gyrase subunit alpha & $\begin{array}{l}51 \% \\
(100 \%)\end{array}$ & $\begin{array}{l}97 \% \\
(100 \%)\end{array}$ & fluoroquinolone \\
\hline GyrB ${ }^{c}$ & DNA gyrase subunit beta & $\begin{array}{l}55 \% \\
(96 \%)\end{array}$ & $\begin{array}{l}99 \% \\
(100 \%)\end{array}$ & fluoroquinolone, aminocoumarin \\
\hline MurA $^{c}$ & $\begin{array}{l}\text { UDP-N-acetylglucosamine } \\
\text { enolpyruvyl transferase }\end{array}$ & $\begin{array}{l}50 \% \\
(99 \%)\end{array}$ & $\begin{array}{l}97 \% \\
(100 \%)\end{array}$ & phosphomycin \\
\hline $\mathrm{RpoB}^{\mathrm{C}}$ & RNA polymerase subunit beta & $\begin{array}{l}55 \% \\
(100 \%)\end{array}$ & $\begin{array}{l}99 \% \\
(100 \%)\end{array}$ & rifamycinrifampicin \\
\hline $\begin{array}{l}\text { Ugd } \\
\text { (PmrE) }\end{array}$ & $\begin{array}{l}\text { UDP-glucose 6-dehydrogenase, } \\
\text { phosphorethanolamine transferase }\end{array}$ & $\begin{array}{l}73 \% \\
(96 \%)\end{array}$ & $\begin{array}{l}98 \% \\
(100 \%)\end{array}$ & peptide antibiotics, polymyxin \\
\hline VanW & glycopeptide resistance protein & $\begin{array}{l}29 \% \\
(97 \%)\end{array}$ & $92 \%(99 \%)$ & glycopeptidesvancomycin \\
\hline
\end{tabular}

${ }^{a}$ Abbreviations used for ARF family designation: ABC: ATP-binding cassette antibiotic efflux pump; MFS: major facilitator superfamily antibiotic efflux pump; RND: resistance-nodulation-cell division antibiotic efflux pump; SMR: small multidrug resistance antibiotic efflux pump

${ }^{\mathrm{b}}$ Best hits indicated as percent sequence similarity (percent sequence coverage)

c Gene carrying resistance-conferring point-mutation(s)

Among those antibiotic resistance conferring factors that act by antibiotic inactivation or molecular target alteration and are virtually ubiquitous across published Providencia genomes [44], the P. vermicola DSM_ 17385 genome encodes an ortholog of an SRT-2 type beta-lactamase [77] conferring resistance to cephalosporins and comprises two identical genes encoding orthologs of the lipid A modifying phosphoethanolamine transferase PmrE [78] that confers resistance to antimicrobial peptides and polymyxin. An ortholog of the NmcR regulator of the class A beta-lactamase NmcA [79] has been found encoded in the P. vermicola 
genome; however, as no gene encoding an NmrA ortholog has been identified, its relevance for beta-lactamase resistance is unclear. Moreover, $P$. vermicola comprises an ortholog of both chloramphenicol acetyltransferase CAT-III [80] and aminoglycoside acetyltransferase AAC (2')-Ia [81]; both factors are widespread in mostly clinical strains of $P$. rettgeri and $P$. stuartii [44].

Among the resistance genes occurring sporadically across the genus, the $P$. vermicola DSM_17385 genome comprises orthologs of the phosphomycin thiol transferase FosA7 [82, 83], the ErmX-type rRNA methyltransferase RsmA [84, 85] and an ortholog of the vancomycin resistance protein VanW $[86,87]$. Several proteins involved in basic cellular processes as DNA gyrase subunits $\mathrm{A}$ and $\mathrm{B}[88,89]$, the RNA polymerase beta subunit [90], translation elongation factor $\mathrm{Tu}$ [91] and UDP-N-acetylglucosamine enolpyruvyl transferase MurA [92] carry one or several point mutations conferring resistance to antibiotics as phosphomycin, fluoroquinolones, elfamycin or rifamycin.

All antibiotic resistance factors identified in $P$. vermicola DSM_17385 appear to be chromosomally encoded; no antibiotic or multi drug resistance (MDR) plasmids as, e.g., those found in P. rettgeri or P. stuartii were identified. Moreover, operons comprising both widespread and sporadically occurring resistance genes are widely distributed over the $P$. vermicola genome. In particular, neither class 1 or 2 integrons nor SXT element that have been described previously to carry accumulated resistance genes in a Providencia isolate assigned to the species $P$. vermicola [35], appear to be present in the genome as IntI1, IntI2 or SXT integrases and qacE, qacEdelta1 or sul1 genes were not identified in the genome under study.

\section{Discussion}

Prior to sequencing of the genome of the $P$. vermicola type strain DSM_17385, three genome sequences from Providencia strains assigned to the species $P$. vermicola had been published. The present comparative analysis using ribosomal typing, phylogenetic reconstruction and digital DNA-DNA hybridization has revealed that the presumed $4 P$. vermicola strains are correctly assigned to the genus Providencia, but do not belong to the same taxonomic species.

Phylogenetic reconstruction from 16S rRNA encoding sequences has been found not sufficiently phylogeny informative to provide sound species delineation in the present context, a problem reported earlier with respect to the genus Providencia [19, 24]. In contrast, phylogenetic reconstruction from housekeeping gene (hMLST) and ribosomal protein encoding gene (rMLST) datasets comprising marker sequences from the nomenclatural type strains of all currently recognized Providencia species has clearly demonstrated that strain DSM_17385 is not closely related to any of the other specific type strains and therefore, expectedly, rightfully represents the independent species $P$. vermicola. In particular, results obtained from the ribosomal marker dataset corroborate the respective earlier conclusions from hMLST based studies [13, 19]. Both phylogenies (Figs. 3 and 4) indicate that $P$. vermicola shares a common ancestor with $P$. rettgeri clade A (comprising strain Dmel1), $P$. rettgeri clade B (proposed to be organized into an independent species named $P$. entomophila) and $P$. huaxiensis before it is phylogenetically related to $P$. alcalifaciens (comprising strain Dmel2) or the still more more distantly related Drosophila melanogaster derived P. sneebia and $P$. burhodogranariea type strains. These results have been fully corroborated by digital DNA-DNA hybridization analysis. Moreover, this systematic situation is mirrored in the apparently "inconclusive" outcome when strain DSM_17385 is typed across 53 ribosomal marker alleles: as the $P$. vermicola type is not closely related to any of the Providencia species represented in the PubMLST database, no existing rST has been assigned to the DSM_17385 genome.

Unexpectedly in view of their previous taxonomic assignment, none of the three presumed $P$. vermicola genome strains appeared closely related to the $P$. vermicola type strain. The outcomes of phylogenetic reconstruction from hMLST and rMLST data sets, digital DNADNA hybridization and ribosomal typing are in line with the assignment of Providencia strain G1 to the species $P$. rettgeri (clade B), whereas strains LLDRA6 and P8538 appear most closely related to the $P$. stuartii / P. thailandensis species complex. The perfect ribosomal typing match of strain P8358 to the species P. vermicola can be judged a bioinformatic artefact as the P8538 genome itself currently serves - both erroneously and misleadingly - as unique reference for this species in the PubMLST database. Taking these results together, Providencia strains G1, LLDRA6 and P8538 appear inconsistently assigned to the taxonomic species $P$. vermicola as represented at the genomic level by the genome sequence of the nomenclatural type strain DSM_17385.

Among the 195 Providencia genomes currently available from the Genbank database uniquely that of strain MR4, assigned to the species $P$. rettgeri, displayed a comparatively closer molecular taxonomic relationship to $P$. vermicola DSM_17385 (Suppl. Figure S2): Providencia strain MR4 might, therefore, be considered a possible candidate for a further $P$. vermicola genome strain. Interestingly, strain MR4 has been isolated from medicinal plant material, more exactly from stem tissue of the Indian mallow, Abutilon indicum, in India (Genbank BioSample SAMN03646990) and is, therefore, geographically related to strain DSM_17385. However, with only 
2132 ORFs identified on as much as 697 contigs, assembly of the MR4 whole genome shotgun is currently rather incomplete, hampering systematic comparative genomics or OrthoANI analyses. In previous studies, comparisons of pair-wise sequence similarities from the hMLST marker set have been employed to critically evaluate the distinct species status of $P$. vermicola, $P$. rettgeri clades $\mathrm{A}$ and $\mathrm{B}$ and $P$. huaxiensis [13]. Extending this approach to the systematic relationship of strains DSM_17385 and MR4 has demonstrated that results from both the hMLST and rMLST datasets are consistent with $P$. vermicola DSM_17385 and the presumed $P$. rettgeri strain MR4 belonging to different rather than to the same taxonomic species.

Taking the above results together, the sequence reported here represents not only the nomenclatural type strain, but the to date unique well-supported $P$. vermicola genome. Comparative genomics at the infra-specific level as, e.g., the identification of $P$. vermicola-specific genes is not feasible with the currently available genome data set.

Within the limits set by the mode of genome assembly, orientation of the 18 scaffolds making up the $P$. vermicola genome sequence alongside the genome of $P$. rettgeri strain Dmel1 revealed a very high degree of genomic synteny. In particular, two important genomic rearrangements that have been described earlier for the P. sneebia genome in comparison to the genomes of further insectderived Providencia strains from the species $P$. rettgeri, $P$. alcalifaciens and $P$. burhodogranariea [45] were absent from the genome of $P$. vermicola DSM_17385.

The genome of $P$. rettgeri Dmel1 was found to share 3127 orthologous genes (78\%) with that of P. vermicola DSM_17385. This is a higher number and fraction of common orthologs than in comparison with insectassociated $P$. alcalifaciens (2672, 70\%), P. burhodogranariea $(2654,70 \%)$ or P. sneebia (2211, 58\%) strains [45], reflecting the closer phylogenetic relationship of $P$. vermicola and P. rettgeri. Given the lack of large block insertions, deletions or rearrangements when comparing both genomes (Fig. 6), genetic speciation understood as the generation of a set of unique genes appears to be the result of many small scale gene gains or losses rather than few large scale events.

No plasmid related to those of insect-associated Providencia bacteria has been identified when assembling the $P$. vermicola genome sequence data, a finding that is in line with the generally high variability in identity, conservation and putative functional designation documented for these genetic elements [45]. The plasmid identified, pPVER1, belongs to a class of small nonconjugative qurD-plasmids found mainly in Morganellaceae bacteria, including strains from several Providencia species [51, 93, 94]. Expression of the qurD gene produces a pentapeptide repeat protein that confers resistance to (fluoro-)quinolone antibiotics by protecting the cellular targets, namely bacterial DNA gyrase and topoisomerase IV, from quinolone binding [95]. The 2683 bp comprising qnrD-plasmids from $P$. rettgeri, $P$. alcalifaciens and $P$. stuartii in addition to the qnrD gene typically contain three colinear open reading frames termed ORF2 through ORF4 encoding hypothetical proteins of yet unknown function. The qnrD gene and ORF2 are located on a putative mic element delineated by $24 \mathrm{bp}$ imperfect inverted repeats. qurD-plasmids from $P$. rettgeri, P.stuartii and $P$. alcalifaciens are highly homologous with pair-wise nucleotide sequence similarities typically ranging between $99.7 \%$ and identity.

pPVER1 from the $P$. vermicola DSM_17385 genome shares the same basic structure found in these qnrD-type plasmids with the important difference that $747 \mathrm{bp}$ from within the putative mic element comprising the qnrD gene itself have been replaced by $1887 \mathrm{bp}$ of a sequence comprising the partially overlapping ORFs $1 \mathrm{a}$ and $1 \mathrm{~b}$ that encode two hypothetical proteins of unknown function. Pairwise sequence similarities between the conserved $1795 \mathrm{bp}$ long segment of pPVER1 carrying ORF2 through ORF4 and the homologous region of Providencia qnrD-type plasmids are high, ranging from 91.7 to $93.0 \%$, whereas no significant similarity can be detected between the ORF1a/b and qurD regions. Most probably, pPVER1 has already been described previously when strain DSM_17385 was used as reference strain in a study investigating qurD genes of Proteeae bacteria [96], but no respective DNA sequence has been published from these studies.

A further qnrD-type plasmid, named p3-000369, has been identified in the nomenclatural type strain of the Providencia species $P$. huaxiensis [4]. Interestingly, the $q n r D$ gene region in this plasmid is replaced by a $979 \mathrm{bp}$ long DNA sequence carrying three colinear ORFs that encode two subunits of a predicted helix-turn-helix transcriptional regulator and a hypothetical protein of unknown function. This region displays no significant similarity to the Providencia qurD-type plasmids or pPVER1, but an almost identical region comprising three orthologous ORFs is encoded by the large $(>200 \mathrm{~kb})$ plasmid of P. rettgeri strain BML2526. Moreover, plasmid p3-000369 contains important deletions in both ORF3 and ORF4.

It appears, therefore, that within the genus Providencia the region carrying the quinolone resistance gene in small qnrD-type plasmids underwent rearrangements including recombination events with both the bacterial chromosome and other plasmids. The rearranged region is part of a putative mic element defined by inverted repeats IRR and IRL carrying, respectively, one and two SNPs when compared for $P$. vermicola pPVER1, $P$. 


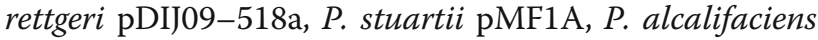
pBT169, and $P$. huaxiensis p3-000369. However, as only part of the putative mic element is rearranged and as no known mobilization structures as, e.g., mob genes were identified on these plasmids, the mechanism leading to these rearrangements is currently unclear. It appears most parsimonious to suppose that rearrangements within qurD-type plasmids of the genus Providencia have occurred subsequently to the appearance of a precursor plasmid carrying qurD within a mic element.

With respect to the nature and organization of identified antibiotic resistance determinants, $P$. vermicola DSM_17385 appears generally similar to non-clinical strains from other Providencia species including $P$. rettgeri and $P$. stuartii. Striking features are both the complete absence of multi drug resistance plasmids and integrons and the related absence of the range of betalactamases found in clinical $P$. rettgeri and $P$. stuartii strains that are the main sources of the MDR phenotype occurring in Providencia [41]. These findings are fully in line with the invertebrate pathogen $P$. vermicola being in its natural environment efficiently excluded from the propagation routes of MDR carrying genetic elements operating between human pathogens. Susceptibility to MDR plasmid acquisition will likely become a major criterion in the evaluation of $P$. vermicola for potential applications in biological pest control.

Gram-negative bacterial pathogens use type III secretion systems (T3SS) or "injectisomes" in a wide variety of physiological contexts to translocate effector proteins simultaneously across their own cell envelope and a eukaryotic host cell or vacuolar membrane. There are different T3SS families named according to the type of ATPase being part of the injectisome. T3SS structural components, but not the effectors translocated by them are encoded by gene clusters that have been transferred between bacteria by horizontal gene transfer [97]. T3SS gene clusters are widespread in Providencia bacteria [44].

The P. vermicola DSM_17385 genome contains a single T3SS island encoding an injectisome of the Inv-Spa family (Fig. 7). This type of T3SS, termed "T3SS-1", is generally associated with host cell invasion, i.e. paradigmatically bacterial uptake by nonphagocytic cells triggered by induced actin reorganization, or intracellular survival as, e.g., in the case of the tsetse fly endosymbiont Sodalis glossinidius [98, 99] or the primary endosymbiont (SZPE) of the Maize weevil, Sitophilus zeamais [100]. The T3SS-1 gene cluster is almost ubiquitously distributed across genomes of Providencia and related Proteus bacteria [44] and has likely been acquired prior to speciation. In particular, a similar T3SS-1 gene cluster has been identified in insect-derived Dmel strains of the species $P$. rettgeri, $P$. alcalifaciens and $P$. sneebia, but not in P. burhodogranariea [45]. Moreover, P. sneebia and $P$. burhodogranariea genomes carry a T3SS-2 injectisome of the Ysc family that is generally associated with the extracellular localization of pathogens and appears to be absent from other Providencia genomes including those of strains $P$. rettgeri Dmel1, $P$. alcalifaciens Dmel1 and the $P$. vermicola strain under study. As T3SS-1 should likely be non-functional in $P$. sneebia due to disruption of the Inv-type ATPase ORF by a premature stop codon [45], it appears that insect-associated $P$. sneebia and $P$. burhodogranariea operate a T3SS-2 for extracellular, insect-associated $P$. vermicola, $P$. rettgeri and $P$. alcalifaciens a T3SS-1 for intracellular localization. As Inv-Spatype injectisomes are widespread across the genus Providencia, but Ysc-type injectisomes appear to date limited to two closely related Providencia species, it is most parsimonious to assume that a common ancestor of $P$. sneebia and $P$. burhodogranariea has acquired a T3SS-2 island by, for instance, horizontal gene transfer, with subsequent mutational inactivation and - in P. burhodogranariea - loss of the original T3SS-1 gene cluster. Interestingly, a Ysc-type injectisome (T3SS-2) is present in the nematode-associated entomopathogenic bacterium Photorhabdus luminescens where it is involved in bacterial survival in the insect hemocoel and resistance to phagocytosis by macrophages [101].

\section{Conclusions}

The genome of the nomenclatural type strain DSM 17385 of the nematode-associated insect-pathogenic enterobacterial species $P$. vermicola has been sequenced and analyzed. The sequence reported represents the first well-supported published genome for the taxonomic species $P$. vermicola to be used as reference in further comparative genomics studies on Providencia bacteria. Genomic analysis has confirmed a closer phylogenetic relationship of $P$. vermicola to the $P$. rettgeri species complex including the recently proposed species $P$. huaxiensis and P. entomophila than to further Providencia species. The genome shows a high degree of synteny when compared to $P$. rettgeri strain Dmel1 isolated from D. melanogaster with $78 \%$ of the identified genes being present in both genomes. As most Providencia strains sequenced to date, P. vermicola DSM_17385 carries a type III secretion system (T3SS-1) with probable function in host cell invasion or intracellular survival and might therefore differ fundamentally in its mechanism of pathogenesis from insect-pathogenic $P$. sneebia or $P$. burhodogranariea bacteria carrying a different type of injectísome. Potentially antibiotic resistance-associated genes comprising numerous efflux pumps and pointmutated house-keeping genes, have been identified across the P. vermicola DSM_17385 genome. However, no antibiotic resistance gene carrying plasmids or mobile genetic elements as those causing MDR phenomena in 
clinical Providencia strains have been found. The only identified plasmid, pPVER1, is derived from a fluoroquinolone resistance plasmid family, but has lost the $q n r D$ resistance gene by recombination from within the plasmid-encoded mic element. We conclude that the invertebrate pathogen $P$. vermicola is in its natural environment efficiently excluded from the propagation routes of MDR carrying genetic elements operating between human pathogens.

\section{Methods}

\section{Bacterial cultivation and DNA extraction}

The nomenclatural type strain $P$. vermicola DSM 17385 (= CIP_108829=OP1) has been received from the German Collection of Microorganisms and Cell Cultures (DSMZ; https://www.dsmz.de). The strain had originally been isolated from surface-sterilized infective juveniles of entomoparasitic Steinernema thermophilum nematodes extracted from larvae of the greater wax moth (Galleria mellonella) [24]. For DNA extraction, bacteria were grown to late log phase in LB medium ( $10 \mathrm{~g} / \mathrm{l}$ Tryptone, $5 \mathrm{~g} / \mathrm{l}$ Yeast Extract, $5 \mathrm{~g} / \mathrm{l}$ sodium chloride, $\mathrm{pH}=7.0$ ) containing $50 \mu \mathrm{g} / \mathrm{ml}$ tetracycline. DNA was extracted using the DNeasy Blood \& Tissue kit protocol for Gram negative bacteria as provided by the manufacturer (Qiagen). Genomic DNA was eluted in $10 \mathrm{mM}$ TrisCl (pH 8.5). DNA quality and quantity were controlled electrophoretically and using a NanoDrop NT-1000 UV spectrophotometer.

\section{Genomic sequencing, assembly and gene annotation}

The whole genome sequencing was performed (SEQ-IT, Kaiserslautern, Germany) on the Illumina MiSeq platform (Illumina, Inc., San Diego, CA), producing $2 \times 250$ bp end-paired reads, generating a total of 1,530,356 reads with $\sim 90 \times$ coverage. The Trimmomatic algorithm (version 0.36) [102] was used to trim all the generated reads and their quality evaluated with in-house scripts using FastQC (version 0.11.9) [103], BedTools (version 2.25.0) [104], and SAMtools (version 1.3.1) [105] algorithms. High-quality filtered reads were subsequently de novo assembled using the SPADES assembler (version 3.7.1) [106].

GLIMMER (version 3) prokaryotic genome automatic annotation software was used to annotate this genome [107]. The size, GC content, number of contigs, N50, L50, average coverage, as well as the number of RNAs, tRNAs, and protein-coding sequences obtained for our isolate, can be found in Table 1. The structural RNA encoding genes were identified using tRNAscan-SE version 2.0.7 [108] and RNAmmer version 1.2 [109]. Finally, the circular multi-track plot was carried out using the 'RCir$\cos ^{\prime} \mathrm{R}$ software package [110].
An in-house pipeline was developed to annotate $P$. vermicola antibiotic resistance genes using the BLASTp algorithm (E-value < 1e-10 and \%identity $250 \%$ ). The queried DSM_17385 genes were identified by mapping protein sequences to the CARD database [111] and tBlastN similarity searches across annotated Providencia genomes. Blast2GO was used to provide automatic high-throughput annotation, gene ontology mapping and functional categorization of $P$. vermicola ORFs identified by GLIMMER. Finally, orthologous genes were evaluated using clusters of orthologous genes (COGs) and eggNOG [112, 113].

The complete plasmid assembly of $p P V E R 1$ was performed utilizing plasmiSPAdes (SPAdes v3.7.1) software with minor manual curation [109].

\section{Prediction of Providencia orthologs and digital DNA-DNA hybridization analysis}

Orthology analysis was conducted on proteomes of $P$. vermicola DSM_17385 and P. rettgeri Dmel1 using Inparanoid software with default parameters [114]. We used a confidence score threshold $=1$ to directly estimate orthology relationships between the identified protein-encoding genes.

Orthologous Average Nucleotide Identity Tool (OAT) software v0.9.31 (https://www.ezbiocloud.net/tools/ orthoani) [49] was used for calculation of pair-wise OrthoANI values for a set of published genomes comprising the four Providencia strains previously assigned to the species $P$. vermicola, the nomenclatural type strains representing all currently recognized taxonomic Providencia species (with the notable exception of the still insufficiently assembled genome of the $P$. stuartii type strain NCTC_11800), and four strains selected on the basis of the hMLST based phylogenetic analysis shown in Suppl. Figure 2 as the most closely related well annotated genomes with respect to the $P$. stuartii type strain (i.e. surrogate type genome of $P$. stuartii strain FDA-ARGOS 645) and to the three presumed $P$. vermicola strains G1, P8358 and LLDRA6.

\section{Whole-genome alignment}

The genomic DNA sequences of $P$. vermicola DSM 17385 and $P$. rettgeri Dmel1 (NZ_CM001774) were aligned using LASTZ (Large-Scale Genome Alignment Tool) (version 1.02.00) with default parameters [115]. Syntenic chromosomal regions were identified using the MAUVE (Multiple Alignment of Conserved Genomic Sequence with Rearrangements) software package. To determine a reasonable value for the Min Locally Collinear Blocks (LCBs), we performed an initial alignment at the default value and then used the LCB weight slider in the MAUVE graphical user interface (GUI) to fix parameters empirically 
eliminating all spurious rearrangements. Sequences were then realigned using the manually determined weight value. The T3SS-1 sequences of $P$. vermicola DSM_17385 and P. rettgeri Dmel1 (NZ_CM001774) were aligned using ClustalW (version 2.1) with default settings [116].

\section{Multilocus sequence typing and phylogenetic reconstruction}

The 16S rRNA, hMLST and rMLST marker genes identified in the annotated $P$. vermicola DSM_17385 genome (Additional files 1 and 2) were used as query in separate BlastN searches [117] across completed genome and whole genome shotgun entries of the Genbank database assigned to the genus Providencia (taxid 586). Orthologous genes from the type strain DSM_4479 (= ATCC_ 29906) of the related enterobacterium Proteus mirabilis were concomitantly identified to serve as outgroup for phylogenetic reconstruction. A whole genome shotgun sequence assigned to 'Candidatus Providencia siddallii' was not considered for sequence typing as preliminary analysis revealed that sequences were too highly divergent to be relevant for the problem under study. For each hMLST and rMLST marker, a set of orthologs from reference genomes representing the 10 recognized Providencia species was generated, each species being represented by its nomenclatural type strain and - if available - further strains spanning the known range of diversity included under this taxon.

Marker alignment and phylogenetic reconstruction were performed using the MEGA software tool [118] at the level of hMLST and rMLST meta-genes comprising concatenations of all respective single marker sequences. Phylogenies were reconstructed using a p-distance matrix-based Neighbor Joining (NJ) method as implemented in MEGA. Tree topology confidence limits were explored in non-parametric bootstrap analyses over 1,000 pseudo-replicates.

For rMLST, $P$. vermicola DSM_17385 genome data and the three published genomes assigned to this species were compared to the PubMLST database [47]. The rMLST typing tool compares each rps, rpl and rpm gene sequence of the query genome to an allele-specific reference database, identifies the closest ribosomal sequence type or types (rST) in the database, and translates this rST similarity into a taxonomic assignment.

\footnotetext{
Abbreviations

ABC: ATP-Binding Cassette antibiotic efflux pump; CAMP: cyclic adenosine monophophate; CARD: Comprehensive Antibiotic Resistance Database; COG: Cluster of Orthologous Genes; GLIMMER: Gene Locator and Interpolated Markov ModelER; GO: Gene Ontology; GUI: Graphical User Interface; hMLST: Multilocus Sequence Typing using housekeeping genes; InvA: Largest inner membrane export protein in T3SS of Salmonella spp; InvSpa: Highly conserved inner membrane proteins in T3SS of Salmonella spp; IRL/IRR: Left-/Right-hand Inverted Repeat; LASTZ: Large-Scale Genome
}

Alignment Tool; LCBs: Locally Collinear Blocks; MAUVE: Multiple Alignment of Conserved Genomic Sequence with Rearrangements; MDR: Multi Drug Resistance; MEGA: Molecular Evolutionary Genetics Analysis software; MFS: Major Facilitator Superfamily antibiotic efflux pump; mic: mobile insertion cassette; NJ: Neighbor Joining algorithm for phylogenetic reconstruction; ORF: Open Reading Frame; PubMLST: Public databases for molecular typing and microbial genome diversity; qnrD: quinolone resistance gene D; rMLST: Multilocus Sequence Typing using ribosomal protein encoding genes; RND: Resistance-Nodulation-cell Division antibiotic efflux pump; rST: ribosomal Sequence Type; SMR: Small Multidrug Resistance antibiotic efflux pump; SNP: Single Nucleotide Polymorphism; SPAdes: St. Petersburg genome assembler; SRT-2: Beta-lactamase conferring resistance to cefotaxime in Serratia marcescens; SXT element: Integrating Conjugative Element, termed for sulfamethoxazole-trimethoprim resistance; T3SS: Type III Secretion System; Ysc: Highly conserved inner membrane proteins in T3SS of Yersinia spp

\section{Supplementary Information}

The online version contains supplementary material available at https://doi. org/10.1186/s12864-021-08027-w. Additional file 1. Sequences of Providencia vermicola DSM_17385 165
rRNA and hMLST marker genes.

Additional file 2. Sequences of Providencia vermicola DSM_17385 rMLST marker genes.

Additional file 3. Sequences of Providencia vermicola DSM_17385 putative antibiotic.resistance-associated proteins

Additional file 4: Suppl. Figure S1. Neighbor Joining (NJ) phylogeny of Providencia bacteria as reconstructed from complete $16 \mathrm{~S}$ ribosomal RNA gene sequences. Terminal branches are labelled by genus, species and strain designations as well as GenBank accession numbers; "TYPE" indicates nomenclatural type strains of the respective taxonomic species. Bacterial strains that have been assigned to the species $P$. vermicola are in bold type. The phylogram representation of the tree has been expanded into a cladogram for better resolution and easier bootstrap support indication. Numbers on branches of the cladogram indicate bootstrap support percentages. The size bar corresponds to $0.5 \%$ sequence divergence along phylogram branches. The $16 \mathrm{~S}$ rRNA encoding sequence from the closely related bacterium Proteus mirabilis has been used as outgroup.

Additional file 5: Suppl. Figure S2. Neighbor Joining (NJ) phylogeny of Providencia bacteria as reconstructed from concatenated complete fusA, gyrB, iles, lepA and leuS gene sequences. Terminal branches are labelled by GenBank accession numbers followed by genus, species and strain designations. Providencia isolates provisionally assigned to the species $P$. vermicola and nomenclatural type strains representing the currently recognized Providencia species are presented in bold type; type strains are indicated by the word "TYPE" following the species designation. Numbers on branches indicate bootstrap support percentages superior to $50 \%$. The size bar corresponds to $2 \%$ sequence divergence. The concatenation of orthologous sequences from the closely related bacterium Proteus mirabilis has been used as outgroup.

Additional file 6: Suppl. Table S1. Pair-wise sequence similarity (in \%) matrices for hMLST (upper right) and rMLST (lower left) data sets across the genus Providencia.

Additional file 7: Suppl. Table S2. Putative antibiotic resistanceassociated factors of $P$. vermicola DSM_17385 as identified in the CARD database.

\section{Acknowledgements}

Not applicable.

\section{Authors' contributions}

GA analyzed the genome sequence data and substantially drafted and revised the manuscript, CS performed the microbiological investigations, prepared DNA sequencing and substantially revised the manuscript, HBG performed the molecular taxonomic analyses, MR designed the work and 
substantially revised the manuscript, AL designed the work, interpreted genomic data and substantially drafted and revised the manuscript. All authors have read and approved the final manuscript.

\section{Funding}

This research has been funded from the EU's Horizon 2020 program within the framework of the Marie Sklodowska-Curie Action OliveFlyBacteria (MSCAIF grant 799952) hosted by CNR-IPSP including an MSCA fellowship to AL and by the German Academic Exchange Service (DAAD) under the project BioPunica (funding IDs 57556890 and 57587958) financed from the budget of the German Federal Foreign Office. The funding bodies had no role in study design, data collection and interpretation, or the decision to submit the work for publication. Open Access funding enabled and organized by Projekt DEAL.

\section{Availability of data and materials}

The $P$. vermicola genome sequence has been deposited in the GenBank database under the accession number JAGSPI 000000000. The version described in this paper is version JAGSPI 010000000. The corresponding BioProject accession number is PRJNA723267 (https://www.ncbi.nlm.nih.gov/ bioproject/PRJNA723267). The $P$. vermicola type strain is available from both the German Collection of Microorganisms and Cell Cultures (DSMZ; https:// www.dsmz.de) under the accession number DSM_17385 and the Biological Resources Centre of Institut Pasteur (CRBIP; https://catalogue-crbip.pasteur.fr) under the accession number CIP_108829T.

\section{Declarations}

\section{Ethics approval and consent to participate}

Not applicable.

\section{Consent for publication}

Not applicable.

\section{Competing interests}

The authors declare that they have no competing interests.

Received: 14 May 2021 Accepted: 20 September 2021

Published online: 02 October 2021

\section{References}

1. Parte AC, Sardà Carbasse J, Meier-Kolthoff JP, Reimer LC, Göker M. List of prokaryotic names with standing in nomenclature (LPSN) moves to the DSMZ. Int J Syst Evol Microbiol. 2020;70(11):5607-12. https://doi.org/10.1 099/ijsem.0.004332.

2. Mohr O'Hara C, Steigerwalt AG, Green D, McDowell M, Hill BC, Brenner DJ, et al. Isolation of Providencia heimbachae from human feces. J Clin Microbiol. 1999;37(9):3048-50. https://doi.org/10.1128/JCM.37.9.3048-3050.1999.

3. O'Hara CM, Brenner FW, Miller JM. Classification, identification, and clinical significance of Proteus, Providencia, and Morganella. Clin Microbiol Rev. 2000;13(4):534-46. https://doi.org/10.1128/cmr.13.4.534-546.2000.

4. Hu Y, Feng $Y$, Zhang $X$, Zong Z. Providencia huaxiensis sp. nov., recovered from a human rectal swab. Int J Syst Evol Microbiol. 2019;69(9):2638-43. https://doi.org/10.1099/ijsem.0.003502.

5. Yoh M, Matsuyama J, Ohnishi M, Takagi K, Miyagi H, Mori K, et al. Importance of Providencia species as a major cause of travellers' diarrhoea. J Med Microbiol. 2005;54(Pt 11):1077-82. https://doi.org/10.1099/jmm.0.45846-0.

6. Shima A, Hinenoya A, Asakura M, Nagita A, Yamasaki S. Prevalence of Providencia strains among children with diarrhea in Japan. Jpn J Infect Dis. 2012;65(6):545-7. https://doi.org/10.7883/yoken.65.545.

7. Shah MM, Odoyo E, Ichinose Y. Epidemiology and pathogenesis of Providencia alcalifaciens infections. Am J Trop Med Hyg. 2019;101(2):290-3. https://doi.org/10.4269/ajtmh.18-0376.

8. Linhares I, Raposo T, Rodrigues A, Almeida A. Frequency and antimicrobial resistance patterns of bacteria implicated in community urinary tract infections: a ten-year surveillance study (2000-2009). BMC Infect Dis. 2013; 13(1):19. https://doi.org/10.1186/1471-2334-13-19.

9. Stock I, Wiedemann B. Natural antibiotic susceptibility of Providencia stuartii, P. rettgeri, P. alcalifaciens and P. rustigianii strains. J Med Microbiol. 1998; 47(7):629-42. https://doi.org/10.1099/00222615-47-7-629.
10. Lee HW, Kang HY, Shin KS, Kim J. Multidrug-resistant Providencia isolates carrying blaPER-1, blaVIM-2, and armA. J Microbiol. 2007;45(3):272-4.

11. Shin S, Jeong SH, Lee H, Hong JS, Park MJ, Song W. Emergence of multidrug-resistant Providencia rettgeri isolates co-producing NDM-1 carbapenemase and PER-1 extended-spectrum $\beta$-lactamase causing a first outbreak in Korea. Ann Clin Microbiol Antimicrob. 2018;17(1):20. https://doi. org/10.1186/s12941-018-0272-y.

12. Liu J, Wang R, Fang M. Clinical and drug resistance characteristics of Providencia stuartii infections in 76 patients. J Int Med Res. 2020;48(10): 300060520962296. https://doi.org/10.1177/0300060520962296.

13. Ksentini I, Gharsallah H, Sahnoun M, Schuster C, Hamli Amri S, Gargouri R, et al. Providencia entomophila sp. nov., a new bacterial species associated with major olive pests in Tunisia. PLoS One. 2019;14(10):e0223943. https:// doi.org/10.1371/journal.pone.0223943.

14. Khan KA, Ansari MJ, Al-Ghamdi A, Nuru A, Harakeh S, labal J. Investigation of gut microbial communities associated with indigenous honey bee (Apis mellifera jemenitica) from two different eco-regions of Saudi Arabia. Saudi J Biol Sci. 2017;24(5):1061-8. https://doi.org/10.1016/j.sjbs.2017.01.055.

15. Gupta AK, Nayduch D, Verma P, Shah B, Ghate HV, Patole MS, et al. Phylogenetic characterization of bacteria in the gut of house flies (Musca domestica L.). FEMS Microbiol Ecol. 2012;79(3):581-93. https://doi.org/1 0.1111/j.1574-6941.2011.01248.x.

16. Maleki-Ravasan N, Ahmadi N, Soroushzadeh Z, Raz AA, Zakeri S, Dinparast DN. New insights into Culturable and Unculturable Bacteria across the life history of medicinal maggots Lucilia sericata (Meigen) (Diptera: Calliphoridae). Front Microbiol. 2020;11:505. https://doi.org/10.3389/fmicb.2 020.00505 .

17. Duan R, Xu H, Gao S, Gao Z, Wang N. Effects of different hosts on bacterial communities of parasitic wasp Nasonia vitripennis. Front Microbiol. 2020;11: 1435. https://doi.org/10.3389/fmicb.2020.01435.

18. Kuzina LV, Peloquin JJ, Vacek DC, Miller TA. Isolation and identification of bacteria associated with adult laboratory Mexican fruit flies, Anastrepha ludens (Diptera: Tephritidae). Curr Microbiol. 2001;42(4):290-4. https://doi. org/10.1007/s002840110219.

19. Juneja P, Lazzaro BP. Providencia sneebia sp. nov. and Providencia burhodogranariea sp. nov., isolated from wild Drosophila melanogaster. Int J Syst Evol Microbiol. 2009;59(Pt 5):1108-11. https://doi.org/10.1099/ijs.0. 000117-0.

20. Galac MR, Lazzaro BP. Comparative pathology of bacteria in the genus Providencia to a natural host, Drosophila melanogaster. Microbes Infect. 2011;13(7):673-83. https://doi.org/10.1016/j.micinf.2011.02.005 Epub 2011 Feb 24. PMID: 21354324; PMCID: PMC3109104.

21. Msaad Guerfali M, Djobbi W, Charaabi K, Hamden H, Fadhl S, Marzouki W, et al. Evaluation of Providencia rettgeri pathogenicity against laboratory Mediterranean fruit fly strain (Ceratitis capitata). PLoS One. 2018;13(5): e0196343. https://doi.org/10.1371/journal.pone.0196343.

22. Hadapad AB, Shettigar SKG, Hire RS. Bacterial communities in the gut of wild and mass-reared Zeugodacus cucurbitae and Bactrocera dorsalis revealed by metagenomic sequencing. BMC Microbiol. 2019;19(Suppl 1):282. https://doi.org/10.1186/s12866-019-1647-8.

23. De Cock M, Virgilio M, Vandamme P, Bourtzis K, De Meyer M, Willems A. Comparative Microbiomics of Tephritid frugivorous pests (Diptera: Tephritidae) from the field: a tale of high variability across and within species. Front Microbiol. 2020;11:1890. https://doi.org/10.3389/fmicb.2020.01890.

24. Somvanshi VS, Lang E, Sträubler B, Spröer C, Schumann P, Ganguly S, et al. Providencia vermicola sp. nov., isolated from infective juveniles of the entomopathogenic nematode Steinernema thermophilum. Int J Syst Evol Microbiol. 2006;56(Pt 3):629-33. https://doi.org/10.1099/ijs.0.63973-0.

25. Yi YK, Park HW, Shrestha S, Seo J, Kim YO, Shin CS, et al. Identification of two entomopathogenic bacteria from a nematode pathogenic to the oriental beetle, Blitopertha orientalis. J Microbiol Biotechnol. 2007;17(6):968-78.

26. Park HW, Kim YO, Ha JS, Youn SH, Kim HH, Bilgrami AL, et al. Effects of associated bacteria on the pathogenicity and reproduction of the insectparasitic nematode Rhabditis blumi (Nematoda: Rhabditida). Can J Microbiol. 2011;57(9):750-8. https://doi.org/10.1139/w11-067.

27. Sangeetha BG, Jayaprakas CA, Siji JV, Rajitha M, Shyni B, Mohandas C. Molecular characterization and amplified ribosomal DNA restriction analysis of entomopathogenic bacteria associated with Rhabditis (Oscheius) spp. 3 Biotech. 2016;6(1):32. https://doi.org/10.1007/s13205-015-0326-1.

28. Jackson TJ, Wang H, Nugent MJ, Griffin CT, Burnell AM, Dowds BCA. Isolation of insect pathogenic bacteria, Providencia rettgeri, from 
Heterorhabditis spp. J Appl Bacteriol. 1995;78:237-44. https://doi.org/1 0.1111/j.1365-2672.1995.tb05022.x.

29. Gegner T, Carrau T, Vilcinskas A, Lee KZ. The infection of Harmonia axyridis by a parasitic nematode is mediated by entomopathogenic bacteria and triggers sex-specific host immune responses. Sci Rep. 2018;8(1):15938. https://doi.org/10.1038/s41598-018-34278-x.

30. Goodrich-Blair H, Clarke DJ. Mutualism and pathogenesis in Xenorhabdus and Photorhabdus: two roads to the same destination. Mol Microbiol. 2007; 64(2):260-8. https://doi.org/10.1111/j.1365-2958.2007.05671.x.

31. Chaston JM, Suen G, Tucker SL, Andersen AW, Bhasin A, Bode E, et al. The entomopathogenic bacterial endosymbionts Xenorhabdus and Photorhabdus: convergent lifestyles from divergent genomes. PLoS One. 2011;6(11):e27909. https://doi.org/10.1371/journal.pone.0027909.

32. Balasubramani G, Deepak P, Sowmiya R, Ramkumar R, Perumal P. Antigonon leptopus: a potent biological source for extermination of fish bacterial pathogens Providencia and Aeromonas. Nat Prod Res. 2015;29(10):958-60. https://doi.org/10.1080/14786419.2014.957696.

33. Boumerdassi H, Djouadi LN, Ouar-Korichi M, Ouzari H-I, Nateche F. Isolation, Characterization of ichtyopathogenic bacterial strain in a lake ecosystem in Algeria. In: Proceedings of the 17th International Days of Biotechnology, 20.23.12.2018. Sousse: ATBT Press; 2018:72.

34. Preena PG, Dharmaratnam A, Raj NS, Raja SA, Nair RR, Swaminathan TR. Antibiotic-resistant Enterobacteriaceae from diseased freshwater goldfish. Arch Microbiol. 2020;203(1):219-31. https://doi.org/10.1007/s00203-020-02 021-8.

35. Rajpara N, Kutar BM, Sinha R, Nag D, Koley H, Ramamurthy T, et al. Role of integrons, plasmids and SXT elements in multidrug resistance of vibrio cholerae and Providencia vermicola obtained from a clinical isolate of diarrhea. Front Microbiol. 2015;6:57. https://doi.org/10.3389/fmicb.2015.00057.

36. Liu Y, Chang H, Li Z, Feng Y, Cheng D, Xue J. Biodegradation of gentamicin by bacterial consortia AMQD4 in synthetic medium and raw gentamicin sewage. Sci Rep. 2017;7(1):11004. https://doi.org/10.1038/s41598-017-11529-x.

37. Islam F, Yasmeen T, Ali Q, Mubin M, Ali S, Arif MS, et al. Copper-resistant bacteria reduces oxidative stress and uptake of copper in lentil plants: potential for bacterial bioremediation. Environ Sci Pollut Res Int. 2016;23(1): 220-33. https://doi.org/10.1007/s11356-015-5354-1.

38. Sharma J, Shamim K, Dubey SK, Meena RM. Metallothionein assisted periplasmic lead sequestration as lead sulfite by Providencia vermicola strain SJ2A. Sci Total Environ. 2017;579:359-65. https://doi.org/10.1016/j. scitotenv.2016.11.089.

39. Tan $L, W u H, C u i H, X u H, X u M, X i a o Y$, et al. Selective adsorption of palladium and platinum from secondary wastewater using Escherichia coli BL21 and Providencia vermicola. Bioprocess Biosyst Eng. 2020;43(10):188597. https://doi.org/10.1007/s00449-020-02378-6.

40. Shukla A, Parmar P, Goswami D, Patel B, Saraf M. Exemplifying an archetypal thorium-EPS complexation by novel thoriotolerant Providencia thoriotolerans AM3. Sci Rep. 2021;11(1):3189. https://doi.org/10.1038/s41598021-82863-4.

41. Piza-Buitrago A, Rincón V, Donato J, Saavedra SY, Duarte C, Morero J, et al. Genome-based characterization of two Colombian clinical Providencia rettgeri isolates co-harboring NDM-1, VIM-2, and other $\beta$-lactamases. BMC Microbiol. 2020;20(1):345. https://doi.org/10.1186/s12866-020-02030-z.

42. Abdallah M, Balshi A. First literature review of carbapenem-resistant Providencia. New Microbes New Infect. 2018;25:16-23. https://doi.org/10.101 6/j.nmni.2018.05.009.

43. Li D, Li R, Ding Z, Ruan X, Luo J, Chen J, et al. Discovery of a novel native bacterium of Providencia sp with high biosorption and oxidation ability of manganese for bioleaching of heavy metal contaminated soils. Chemosphere. 2020:241:125039. https://doi.org/10.1016/..chemosphere.2019.125039.

44. Yuan C, Wei Y, Zhang S, Cheng J, Cheng X, Qian C, et al. Comparative genomic analysis reveals genetic mechanisms of the variety of pathogenicity, antibiotic resistance, and environmental adaptation of Providencia genus. Front Microbiol. 2020;11:572642. https://doi.org/10.3389/ fmicb.2020.572642.

45. Galac MR, Lazzaro BP. Comparative genomics of bacteria in the genus Providencia isolated from wild Drosophila melanogaster. BMC Genomics. 2012;13(1):612. https://doi.org/10.1186/1471-2164-13-612.

46. Tatusov RL, Natale DA, Garkavtsev IV, Tatusova TA, Shankavaram UT, Rao BS, et al. The COG database: new developments in phylogenetic classification of proteins from complete genomes. Nucleic Acids Res. 2001;29(1):22-8. https://doi.org/10.1093/nar/29.1.22.
47. Jolley KA, Bliss CM, Bennett JS, Bratcher HB, Brehony C, Colles FM, et al. Ribosomal multilocus sequence typing: universal characterization of bacteria from domain to strain. Microbiology. 2012;158(Pt 4):1005-15. https://doi. org/10.1099/mic.0.055459-0.

48. Lalucat J, Mulet M, Gomila M, García-Valdés E. Genomics in bacterial taxonomy: impact on the genus Pseudomonas. Genes (Basel). 2020;11(2):139. https://doi.org/10.3390/genes11020139.

49. Lee I, Ouk Kim Y, Park SC, Chun J. OrthoANI: an improved algorithm and software for calculating average nucleotide identity. Int I Syst Evol Microbiol. 2016;66(2):1100-3. https://doi.org/10.1099/ijsem.0.000760.

50. Miró E, Grünbaum F, Gómez L, Rivera A, Mirelis B, Coll P, et al. Characterization of aminoglycoside-modifying enzymes in enterobacteriaceae clinical strains and characterization of the plasmids implicated in their diffusion. Microb Drug Resist. 2013;19(2):94-9. https://doi. org/10.1089/mdr.2012.0125.

51. Guillard T, Cambau E, Neuwirth C, Nenninger T, Mbadi A, Brasme L, et al. Description of a 2,683-base-pair plasmid containing gnrD in two Providencia rettgeri isolates. Antimicrob Agents Chemother. 2012;56(1):5658. https://doi.org/10.1128/AAC.00081-11.

52. Schuldiner S. EmrE, a model for studying evolution and mechanism of ioncoupled transporters. Biochim Biophys Acta. 2009;1794(5):748-62. https:// doi.org/10.1016/j.bbapap.2008.12.018.

53. Bengoechea JA, Skurnik M. Temperature-regulated efflux pump/potassium antiporter system mediates resistance to cationic antimicrobial peptides in Yersinia. Mol Microbiol. 2000;37(1):67-80. https://doi.org/10.1046/j.1365-2 958.2000.01956.x.

54. Fàbrega A, Martin RG, Rosner JL, Tavio MM, Vila J. Constitutive SoxS expression in a fluoroquinolone-resistant strain with a truncated SoxR protein and identification of a new member of the marA-soxS-rob regulon, mdtG. Antimicrob Agents Chemother. 2010;54(3):1218-25. https://doi.org/1 0.1128/AAC.00944-09.

55. Srinivasan VB, Rajamohan G. KpnEF, a new member of the Klebsiella pneumoniae cell envelope stress response regulon, is an SMR-type efflux pump involved in broad-spectrum antimicrobial resistance. Antimicrob Agents Chemother. 2013;57(9):4449-62. https://doi.org/10.1128/AAC.02284-12.

56. Lomovskaya O, Lewis K. Emr, an Escherichia coli locus for multidrug resistance. Proc Natl Acad Sci U S A. 1992;89(19):8938-42. https://doi.org/1 0.1073/pnas.89.19.8938.

57. Srinivasan VB, Singh BB, Priyadarshi N, Chauhan NK, Rajamohan G. Role of novel multidrug efflux pump involved in drug resistance in Klebsiella pneumoniae. PLoS One. 2014;9(5):e96288. https://doi.org/10.1371/journal. pone.0096288.

58. Kobayashi N, Nishino K, Hirata T, Yamaguchi A. Membrane topology of ABCtype macrolide antibiotic exporter MacB in Escherichia coli. FEBS Lett. 2003; 546(2-3):241-6. https://doi.org/10.1016/s0014-5793(03)00579-9.

59. Xu Y, Sim SH, Song S, Piao S, Kim HM, Jin XL, et al. The tip region of the MacA alpha-hairpin is important for the binding to TolC to the Escherichia coli MacAB-TolC pump. Biochem Biophys Res Commun. 2010;394(4):962-5. https://doi.org/10.1016/j.bbrc.2010.03.097.

60. Srinivasan VB, Rajamohan G, Gebreyes WA. Role of AbeS, a novel efflux pump of the SMR family of transporters, in resistance to antimicrobial agents in Acinetobacter baumannii. Antimicrob Agents Chemother. 2009; 53(12):5312-6. https://doi.org/10.1128/AAC.00748-09.

61. Leclercq SO, Wang C, Zhu Y, Wu H, Du X, Liu Z, et al. Diversity of the tetracycline Mobilome within a Chinese pig manure sample. Appl Environ Microbiol. 2016;82(21):6454-62. https://doi.org/10.1128/AEM.01754-16.

62. Nagakubo S, Nishino K, Hirata T, Yamaguchi A. The putative response regulator BaeR stimulates multidrug resistance of Escherichia coli via a novel multidrug exporter system, MdtABC. J Bacteriol. 2002;184(15):4161-7. https://doi.org/10.1128/jb.184.15.4161-4167.2002.

63. Du D, Wang Z, James NR, Voss JE, Klimont E, Ohene-Agyei T, et al. Structure of the AcrAB-TolC multidrug efflux pump. Nature. 2014;509(7501):512-5. https://doi.org/10.1038/nature13205.

64. Lomovskaya $\mathrm{O}$, Lewis $\mathrm{K}$, Matin $\mathrm{A}$. EmrR is a negative regulator of the Escherichia coli multidrug resistance pump EmrAB. J Bacteriol. 1995;177(9): 2328-34. https://doi.org/10.1128/jb.177.9.2328-2334.1995.

65. Aendekerk S, Diggle SP, Song Z, Høiby N, Cornelis P, Williams P, et al. The MexGHI-OpmD multidrug efflux pump controls growth, antibiotic susceptibility and virulence in Pseudomonas aeruginosa via 4-quinolonedependent cell-to-cell communication. Microbiology. 2005;151(Pt 4):111325. https://doi.org/10.1099/mic.0.27631-0. 
66. Hirakawa H, Inazumi Y, Masaki T, Hirata T, Yamaguchi A. Indole induces the expression of multidrug exporter genes in Escherichia coli. Mol Microbiol. 2005;55(4):1113-26. https://doi.org/10.1111/j.1365-2958.2004.04449.x.

67. Fonseca EL, Marin MA, Encinas F, Vicente AC. Full characterization of the integrative and conjugative element carrying the metallo- $\beta$-lactamase Bla SPM-1 and bicyclomycin bcr1 resistance genes found in the pandemic Pseudomonas aeruginosa clone SP/ST277. J Antimicrob Chemother. 2015; 70(9):2547-50. https://doi.org/10.1093/jac/dkv152.

68. Schneiders T, Amyes SG, Levy SB. Role of AcrR and ramA in fluoroquinolone resistance in clinical Klebsiella pneumoniae isolates from Singapore. Antimicrob Agents Chemother. 2003;47(9):2831-7. https://doi.org/10.112 8/aac.47.9.2831-2837.2003.

69. Webber MA, Talukder A, Piddock LJ. Contribution of mutation at amino acid 45 of AcrR to acrB expression and ciprofloxacin resistance in clinical and veterinary Escherichia coli isolates. Antimicrob Agents Chemother. 2005; 49(10):4390-2. https://doi.org/10.1128/AAC.49.10.4390-4392.2005.

70. Pessi G, Williams F, Hindle Z, Heurlier K, Holden MT, Cámara M, et al. The global posttranscriptional regulator RsmA modulates production of virulence determinants and $\mathrm{N}$-acylhomoserine lactones in Pseudomonas aeruginosa. J Bacteriol. 2001;183(22):6676-83. https://doi.org/10.1128/JB.1 83.22.6676-6683.2001 Erratum in: J Bacteriol 2002;184(1):335

71. Mulcahy H, O'Callaghan J, O'Grady EP, Adams C, O'Gara F. The posttranscriptional regulator RsmA plays a role in the interaction between Pseudomonas aeruginosa and human airway epithelial cells by positively regulating the type III secretion system. Infect Immun. 2006;74(5):3012-5. https://doi.org/10.1128/IAl.74.5.3012-3015.2006.

72. Nishino K, Senda Y, Yamaguchi A. CRP regulator modulates multidrug resistance of Escherichia coli by repressing the mdtEF multidrug efflux genes. J Antibiot. 2008;61(3):120-7. https://doi.org/10.1038/ja.2008.120.

73. Köhler T, Epp SF, Curty LK, Pechère JC. Characterization of MexT, the regulator of the MexE-MexF-OprN multidrug efflux system of Pseudomonas aeruginosa. J Bacteriol. 1999;181(20):6300-5. https://doi.org/10.1128/JB.181.2 0.6300-6305.1999.

74. Nishino K, Yamaguchi A. EvgA of the two-component signal transduction system modulates production of the yhiUV multidrug transporter in Escherichia coli. J Bacteriol. 2002;184(8):2319-23. https://doi.org/10.1128/jb.1 84.8.2319-2323.2002

75. Nishino K, Yamaguchi A. Role of histone-like protein H-NS in multidrug resistance of Escherichia coli. J Bacteriol. 2004;186(5):1423-9. https://doi. org/10.1128/jb.186.5.1423-1429.2004.

76. Doménech-Sánchez A, Hernández-Allés S, Martínez-Martínez L, Benedí VJ, Albertí S. Identification and characterization of a new porin gene of Klebsiella pneumoniae: its role in beta-lactam antibiotic resistance. J Bacteriol. 1999; 181(9):2726-32. https://doi.org/10.1128/JB.181.9.2726-2732.1999.

77. Wu LT, Tsou MF, Wu HJ, Chen HE, Chuang YC, Yu WL. Survey of CTXM-3 extended-spectrum beta-lactamase (ESBL) among cefotaximeresistant Serratia marcescens at a medical center in middle Taiwan. Diagn Microbiol Infect Dis. 2004;49(2):125-9. https://doi.org/10.1016/j.dia gmicrobio.2004.02.004

78. Gunn JS, Lim KB, Krueger J, Kim K, Guo L, Hackett M, et al. PmrA-PmrBregulated genes necessary for 4-aminoarabinose lipid a modification and polymyxin resistance. Mol Microbiol. 1998;27(6):1171-82. https://doi.org/10.1 046/j.1365-2958.1998.00757.x.

79. Naas T, Nordmann P. Analysis of a carbapenem-hydrolyzing class a betalactamase from Enterobacter cloacae and of its LysR-type regulatory protein. Proc Natl Acad Sci U S A. 1994;91(16):7693-7. https://doi.org/10.1073/pnas. 91.16.7693.

80. Murray IA, Hawkins AR, Keyte JW, Shaw W. Nucleotide sequence analysis and overexpression of the gene encoding a type III chloramphenicol acetyltransferase. Biochem J. 1988;252(1):173-9. https://doi.org/10.1042/bj2 520173.

81. Rather PN, Orosz E, Shaw KJ, Hare R, Miller G. Characterization and transcriptional regulation of the $2^{\prime}-\mathrm{N}$-acetyltransferase gene from Providencia stuartii. J Bacteriol. 1993;175(20):6492-8. https://doi.org/10.1128/ jb.175.20.6492-6498.1993.

82. Rehman MA, Yin X, Persaud-Lachhman MG, Diarra MS. First detection of a Fosfomycin resistance gene, fosA7, in Salmonella enterica Serovar Heidelberg isolated from broiler chickens. Antimicrob Agents Chemother. 2017;61(8):e00410-7. https://doi.org/10.1128/AAC.00410-17.

83. Milner KA, Bay DC, Alexander D, Walkty A, Karlowsky JA, Mulvey MR, et al. Identification and characterization of a novel FosA7 member from
Fosfomycin-resistant Escherichia coli clinical isolates from Canadian hospitals. Antimicrob Agents Chemother. 2020;65(1):e00865-20. https://doi. org/10.1128/AAC.00865-20.

84. Leclerca R, Courvalin P. Bacterial resistance to macrolide, lincosamide, and streptogramin antibiotics by target modification. Antimicrob Agents Chemother. 1991;35(7):1267-72. https://doi.org/10.1128/aac.35.7.1267 Erratum in: Antimicrob Agents Chemother 1991;35(10):2165.

85. Wachino J, Arakawa Y. Exogenously acquired 16S rRNA methyltransferases found in aminoglycoside-resistant pathogenic gram-negative bacteria: an update. Drug Resist Updat. 2012;15(3):133-48. https://doi.org/10.1016/j. drup.2012.05.001.

86. McKessar SJ, Berry AM, Bell JM, Turnidge JD, Paton JC. Genetic characterization of vanG, a novel vancomycin resistance locus of enterococcus faecalis. Antimicrob Agents Chemother. 2000;44(11):3224-8. https://doi.org/10.1128/aac.44.11.3224-3228.2000.

87. Courvalin P. Vancomycin resistance in gram-positive cocci. Clin Infect Dis. 2006;42(Suppl 1):S25-34. https://doi.org/10.1086/491711.

88. Spigaglia P, Barbanti F, Mastrantonio P, Brazier JS, Barbut F, Delmée M, et al. On behalf of the European study group on Esgcd. Fluoroquinolone resistance in Clostridium difficile isolates from a prospective study of $\mathrm{C}$. difficile infections in Europe. J Med Microbiol. 2008;57(Pt 6):784-9. https:// doi.org/10.1099/jmm.0.47738-0.

89. Walkty A, Boyd DA, Gravel D, Hutchinson J, McGeer A, Moore D, et al. Canadian nosocomial infection surveillance program. Molecular characterization of moxifloxacin resistance from Canadian Clostridium difficile clinical isolates. Diagn Microbiol Infect Dis. 2010;66(4):419-24. https://doi.org/10.1016/j.diagmicrobio.2009.12.002.

90. Mariam DH, Mengistu Y, Hoffner SE, Andersson DI. Effect of rpoB mutations conferring rifampin resistance on fitness of mycobacterium tuberculosis. Antimicrob Agents Chemother. 2004;48(4):1289-94. https://doi.org/10.112 8/aac.48.4.1289-1294.2004.

91. Zeef LA, Bosch L, Anborgh PH, Cetin R, Parmeggiani A, Hilgenfeld R. Pulvomycin-resistant mutants of E.coli elongation factor Tu. EMBO J. 1994; 13(21):5113-20. https://doi.org/10.1002/j.1460-2075.1994.tb06840.x.

92. Fu Z, Ma Y, Chen C, Guo Y, Hu F, Liu Y, et al. Prevalence of Fosfomycin resistance and mutations in murA, glpT, and uhpT in methicillin-resistant Staphylococcus aureus strains isolated from blood and cerebrospinal fluid samples. Front Microbiol. 2016;6:1544. https://doi.org/10.3389/fmicb.2015.01 544.

93. Yanat B, Rodríguez-Martínez JM, Touati A. Plasmid-mediated quinolone resistance in Enterobacteriaceae: a systematic review with a focus on Mediterranean countries. Eur J Clin Microbiol Infect Dis. 2017;36(3):421-35. https://doi.org/10.1007/s10096-016-2847-X.

94. Yassine I, Rafei R, Osman M, Mallat H, Dabboussi F, Hamze M. Plasmidmediated quinolone resistance: mechanisms, detection, and epidemiology in the Arab countries. Infect Genet Evol. 2019;76:104020. https://doi.org/10.1 016/j.meegid.2019.104020.

95. Pham TDM, Ziora ZM, Blaskovich MAT. Quinolone antibiotics. Medchemcomm. 2019;10(10):1719-39. https://doi.org/10.1039/c9md00120d.

96. Guillard T, Grillon A, de Champs C, Cartier C, Madoux J, Berçot B, et al. Mobile insertion cassette elements found in small non-transmissible plasmids in Proteeae may explain qnrD mobilization. PLoS One. 2014;9(2): e87801. https://doi.org/10.1371/journal.pone.0087801.

97. Troisfontaines $P$, Cornelis GR. Type III secretion: more systems than you think. Physiology (Bethesda). 2005;20(5):326-39. https://doi.org/10.1152/ physiol.00011.2005.

98. Dale C, Young SA, Haydon DT, Welburn SC. The insect endosymbiont Sodalis glossinidius utilizes a type III secretion system for cell invasion. Proc Natl Acad Sci U S A. 2001;98(4):1883-8. https://doi.org/10.1073/pnas.021450998.

99. Dale $\mathrm{C}$, Jones $\mathrm{T}$, Pontes $\mathrm{M}$. Degenerative evolution and functional diversification of type-III secretion systems in the insect endosymbiont Sodalis glossinidius. Mol Biol Evol. 2005;22(3):758-66. https://doi.org/10.1093/molbev/msi061 Erratum in: Mol Biol Evol. 2005; 22(4):1160.

100. Dale C, Plague GR, Wang B, Ochman H, Moran NA. Type III secretion systems and the evolution of mutualistic endosymbiosis. Proc Natl Acad Sci U S A. 2002;99(19):12397-402. https://doi.org/10.1073/pnas.182213299.

101. Brugirard-Ricaud K, Duchaud E, Givaudan A, Girard PA, Kunst F, Boemare N, et al. Site-specific antiphagocytic function of the Photorhabdus luminescens type III secretion system during insect colonization. Cell Microbiol. 2005;7(3): 363-71. https://doi.org/10.1111/j.1462-5822.2004.00466.x. 
102. Bolger AM, Lohse M, Usadel B. Trimmomatic: a flexible trimmer for Illumina sequence data. Bioinformatics. 2014;30(15):2114-20. https://doi.org/10.1093/ bioinformatics/btu170.

103. Andrews S. FastQC: a quality control tool for high throughput sequence data. 2010. https:/www.bioinformatics.babraham.ac.uk/projects/fastqc/

104. Quinlan AR, Hall IM. BEDTools: a flexible suite of utilities for comparing genomic features. Bioinformatics. 2010;26(6):841-2. https://doi.org/10.1093/ bioinformatics/btq033.

105. Li H, Handsaker B, Wysoker A, Fennell T, Ruan J, Homer N, et al. 1000 genome project data processing subgroup. The sequence alignment/map format and SAMtools. Bioinformatics. 2009;25(16):2078-9. https://doi.org/1 0.1093/bioinformatics/btp352.

106. Bankevich A, Nurk S, Antipov D, Gurevich AA, Dvorkin M, Kulikov AS, et al. SPAdes: a new genome assembly algorithm and its applications to singlecell sequencing. J Comput Biol. 2012;19(5):455-77. https://doi.org/10.1089/ $\mathrm{cmb} .2012 .0021$.

107. Delcher AL, Bratke KA, Powers EC, Salzberg SL. Identifying bacterial genes and endosymbiont DNA with Glimmer. Bioinformatics. 2007;23(6):673-9. https://doi.org/10.1093/bioinformatics/btm009.

108. Lowe TM, Eddy SR. tRNAscan-SE: a program for improved detection of transfer RNA genes in genomic sequence. Nucleic Acids Res. 1997;25(5): 955-64. https://doi.org/10.1093/nar/25.5.955.

109. Lagesen $K$, Hallin P, Rødland EA, Staerfeldt HH, Rognes T, Ussery DW. RNAmmer: consistent and rapid annotation of ribosomal RNA genes. Nucleic Acids Res. 2007;35(9):3100-8. https://doi.org/10.1093/nar/gkm160.

110. Zhang $\mathrm{H}$, Meltzer $\mathrm{P}$, Davis S. RCircos: an R package for Circos $2 \mathrm{D}$ track plots. BMC Bioinformatics. 2013;14(1):244. https://doi.org/10.1186/1471-21 05-14-244.

111. Alcock BP, Raphenya AR, Lau TTY, Tsang KK, Bouchard M, Edalatmand A, et al. CARD 2020: antibiotic resistome surveillance with the comprehensive antibiotic resistance database. Nucleic Acids Res. 2020;48(D1):D517-25. https://doi.org/10.1093/nar/gkz935.

112. Galperin MY, Makarova KS, Wolf Yl, Koonin EV. Expanded microbial genome coverage and improved protein family annotation in the COG database. Nucleic Acids Res. 2015;43(Database issue):D261-9. https://doi.org/10.1093/ nar/gku1223.

113. Huerta-Cepas J, Szklarczyk D, Forslund K, Cook H, Heller D, Walter MC, et al, eggNOG 4.5: a hierarchical orthology framework with improved functional annotations for eukaryotic, prokaryotic and viral sequences. Nucleic Acids Res. 2016;44(D1):D286-93. https://doi.org/10.1093/nar/gkv1248.

114. Remm M, Storm CE, Sonnhammer EL. Automatic clustering of orthologs and in-paralogs from pairwise species comparisons. J Mol Biol. 2001;314(5): 1041-52. https://doi.org/10.1006/jmbi.2000.5197.

115. Harris RS. Improved pairwise alignment of genomic DNA: The Pennsylvania State University; 2007. https://search.proquest.com/openview/ bc77cca0fb9390b44b9ef572fb574322/1?cbl=18750\&diss=y\&pq-origsite $=$ gscholar

116. Larkin MA, Blackshields G, Brown NP, Chenna R, McGettigan PA, McWilliam $H$, et al. Clustal W and Clustal X version 2.0. Bioinformatics. 2007;23(21): 2947-8. https://doi.org/10.1093/bioinformatics/btm404.

117. Zhang Z, Schwartz S, Wagner L, Miller W. A greedy algorithm for aligning DNA sequences. J Comput Biol. 2000;7(1-2):203-14. https://doi.org/10.1 089/10665270050081478.

118. Tamura K, Stecher G, Peterson D, Filipski A, Kumar S. MEGA6: molecular evolutionary genetics analysis version 6.0. Mol Biol Evol. 2013;30(12):2725-9. https://doi.org/10.1093/molbev/mst197.

\section{Publisher's Note}

Springer Nature remains neutral with regard to jurisdictional claims in published maps and institutional affiliations.

Ready to submit your research? Choose BMC and benefit from:

- fast, convenient online submission

- thorough peer review by experienced researchers in your field

- rapid publication on acceptance

- support for research data, including large and complex data types

- gold Open Access which fosters wider collaboration and increased citations

- maximum visibility for your research: over $100 \mathrm{M}$ website views per year

At BMC, research is always in progress.

Learn more biomedcentral.com/submissions 